Uppermost Triassic to Lower Jurassic sediments of the island of Ireland and its surrounding basins.

\author{
${ }^{1}$ Geological Survey of Northern Ireland, Dundonald House, Upper Newtownards Road, Belfast, BT4 3SB, \\ Northern Ireland \\ ${ }^{2}$ Merlin Energy Resources Ltd., Newberry House, New St, Herefordshire, HR8 2EJ, England, \\ ${ }^{3}$ Ulster Museum, Belfast, BT9 5AB, Northern Ireland \\ ${ }^{4}$ Geosciences Research Group, GEES, University of Birmingham, B15 2TT, England
}

\title{
Abstract
}

The uppermost Triassic to Lower Jurassic interval has not been extensively studied across the island of Ireland. This paper seeks to redress that situation and presents a synthesis of records of the uppermost Triassic and Lower Jurassic from both onshore and offshore basins as well as describing the sedimentological characteristics of the main lithostratigraphical units encountered. Existing data have been supplemented with a re-examination and logging of some outcrops and the integration of data from recent hydrocarbon exploration wells and boreholes. The Late Triassic Penarth Group and Early Jurassic Lias Group can be recognised across the Republic of Ireland and Northern Ireland. In some onshore basins, almost $600 \mathrm{~m}$ of strata are recorded, however in offshore basins thicknesses in excess of two kilometres for the Lower Jurassic have now been recognised, although little detailed information is currently available. The transition from the Triassic to the Jurassic was a period of marked global sea-level rise and climatic change (warming) and this is reflected in the lithostratigraphical record of these sediments in the basins of Northern Ireland and offshore basins of the Republic of Ireland. In general, the sediments of this interval are thicker than those in Great Britain and have potential for detailed study of climatic and sea-level fluctuation.

KEYWORDS: Stratigraphy, Basins, Ireland, Triassic, Jurassic, Penarth Group, Lias Group.

\section{Introduction and geological setting}

Onshore records of uppermost Triassic and Lower Jurassic rocks on the island of Ireland are restricted to narrow outcrops around the coasts of counties Antrim and Londonderry in Northern Ireland that have been much affected by Holocene and Recent landslip. Inland 
from the coastal sections the Triassic-Jurassic rocks are usually concealed beneath Cretaceous chalk, Paleogene lavas and locally Oligocene clays and lignites. The thickest and most complete onshore records of uppermost Triassic and Lower Jurassic sediments are from deep boreholes that have penetrated the younger cover rocks. Large parts of the concealed basins remain unexplored and so our understanding of the nature, extent and palaeogeography of the Late Triassic and Early Jurassic in this region is somewhat constrained. This lack of knowledge is compounded by the absence of detailed studies in recent years, an important exception being the study of the Larne foreshore (Simms \& Jeram, 2007). However, a growing number of cores have become available (Boomer et al. 202Xa, 202Xb, Raine et al. 202X) and further outcrops described (Raine et al. 202X) the results of these are included in the current volume. Uppermost Triassic and Lower Jurassic sediments are both widespread and thickly developed in a number of the offshore basins around the island of Ireland, particularly in the Republic of Ireland and these are also detailed below. The principal focus of this study is to outline the lithostratigraphic framework and sedimentological characteristics of onshore strata (principally occurring in Northern Ireland) in light of new records and to set this in the context of the individual basins and their wider relationship with offshore basins. The interval suffers from an absence of continuous faunal records and integration of ammonite biostratigraphy, calcareous microfossils, palynology and geochemistry with the sedimentology and lithostratigraphy will be required to unpick events within this interval.

The basin configuration during the Late Triassic and Early Jurassic across the north of the island of Ireland largely follows the configuration of pre-existing Permo-Triassic rift basins, located onshore and offshore around the island (Figure 1). Comparing Jurassic sediment thicknesses between different areas suggests that it was a time without major differential fault movement between the basins. It is not known to what extent the gravity highs between the Larne and Lough Neagh basins and the Lough Foyle and Rathlin basins (Figure 2), or the basement rocks along the Highland Border influenced sedimentation at this time. Sediment thickness and facies variation between the Magilligan Borehole (Bazley et al. 1997) (central Lough Foyle Basin) and onto the gravity high do not appear to vary much but, towards the south, the unconformity with Upper Cretaceous rocks (Chalk Group) progressively cuts out the Lias Group, Penarth Group, Mercia Mudstone Group and much of 
the underlying Sherwood Sandstone Group, suggesting that there was pronounced uplift and tilting of this area during the Early Cretaceous. Cretaceous strata have been shown to progressively onlap the Highland Border Ridge (HBR) (Fletcher, 1977) and the only other Mesozoic aged rocks found across the border ridge are small outcrops of the Triassic Sherwood Sandstone Group. Jurassic sediments may be preserved within several small NNE-SSW graben (identified by gravity data) that cross the HBR, but they have not yet been explored by drilling. The only boreholes drilled over the HBR have recorded either Ulster White Limestone Formation of the Chalk Group or Sherwood Sandstone Group (GSNI unpublished records). If the Rhaetian and Hettangian/Sinemurian seas did not extend over the HBR, then a connection may have been established via what is now the offshore part of the Larne Basin.

Sedimentation during this interval was constrained by the marine inundation of a number of pre-existing basins as a result of continued sea-level rise and / or thermal subsidence on the edge of what is known as the Irish Massif. The extent of the sea in this area during the Late Triassic and Early Jurassic is somewhat speculative, with Naylor and Shannon (1982) and Ziegler (1990) having proposed that the whole of the island of Ireland was emergent during this time, and Naylor (1992) having shown a series of emergent areas on his paleogeographic reconstruction.

In Northern Ireland, uppermost Triassic and Lower Jurassic rocks are restricted to the Permo-Triassic rift basins (Rathlin, Lough Foyle, Larne and Lough Neagh). Of these, the Rathlin, Lough Foyle and Larne basins extend offshore, whilst the Lough Neagh Basin is located entirely onshore. The Larne and Lough Neagh basins are separated by a NW-SE trending interbasinal high (Figure 1) and these two basins are separated from the Rathlin and Lough Foyle basins to the north by a more pronounced basement high, dominated by Dalradian metasediments, representing a continuation of the HBR from Scotland.

As in other parts of the UK, the uppermost Triassic and Lower Jurassic succession in Northern Ireland can be divided into the Penarth Group and the Lias Group (Warrington, 1997). The Penarth Group is a Triassic aged unit of fine-grained siliciclastic sediments, with 
some carbonate-rich intervals deposited in a range of restricted marine and marginal marine to brackish environments. The Lias Group is represented by Jurassic open marine, blue-grey claystones and siltstones, with fossils abundant locally.

Beyond the confines of these basins, Jurassic rocks are encountered onshore in Ireland at only two locations. At Cloyne, near the city of Cork, clays infilling a karstic depression in the Carboniferous limestone yielded a palynoflora that indicates a late Early Jurassic to MidJurassic age (Higgs and Beese, 1986). At Piltown, County Kilkenny, clastic sediments intercepted by exploratory boreholes into karstified Carboniferous limestones yielded a palynoflora indicating a Late Jurassic to Early Cretaceous (Kimmeridgian to Berriasian) age (Higgs and Jones, 2000).

Lias Group and Penarth Group sediments are extensively developed in offshore basins to the east and south of Ireland, including the Kish Bank, North and South Celtic Sea basins and the Fastnet Basin (Dobson and Whittington, 1979; Shannon, 1995; Ewins and Shannon 1995; Kessler and Sachs, 1995; Murphy and Ainsworth, 1991) basins. Well-developed successions of the Lias Group span the Hettangian to Toarcian interval and are overlain, in the North Celtic Sea Basin, by marine Middle Jurassic sediments (Aalenian-Bathonian). Sedimentation in some of these depositional areas continue uninterrupted into the UK offshore area, for example the UK part of the South Celtic Sea Basin, the St George's Channel Basin and the Bristol Channel Basin (Tappin et al., 1994). Thick Lower Jurassic successions are also present in the western offshore Ireland areas, including the Goban Spur (Colin et al., 1992), Porcupine (Croker and Klemperer, 1989), Slyne and Erris basins (Trueblood, 1992; Dancer et al., 1999, 2005; Stoker et al., 2017; Tate and Dobson 1989). Penarth Group successions are also proven in many of these basins although they are not well documented.

It should be noted that for the Republic of Ireland offshore area no formalised lithostratigraphic nomenclature exists. At the time of writing a new lithostratigraphic scheme is being developed by a consortium of companies led by Merlin Energy Resources 
Ltd (hereafter referred to as Merlin, in prep) as part of a regional study commissioned by the Petroleum Affairs Division (PAD) and the Petroleum Infrastructure Programme ('PIP') of the Republic of Ireland government. The results will be published in 2020, but had not been released at the time of writing of the current publication. This new scheme will define a new lithostratigraphic (and biostratigraphic and sequence stratigraphic) scheme for the whole of offshore Ireland. For the Penarth and Lias groups new formations and members will be defined, but some existing UK onshore terms will also be retained in certain instances. In the current paper, therefore, recourse has to be made to the several informal lithostratigraphic schemes that exist for the area pending the publication of the new Merlin - PAD scheme.

On the UK Continental Shelf Triassic to Early Jurassic rocks are located within the Rathlin and Foyle basins that extend up the sound of Jura between Islay and the Mull of Kintyre. A small area of Triassic and Jurassic sediments also occurs within a NW-trending half graben called the Loch Indaal Basin (Figure 1), thickening toward the NW and bounded by the Leannan Loch Gruinart fault system (Evans et al., 1980). 


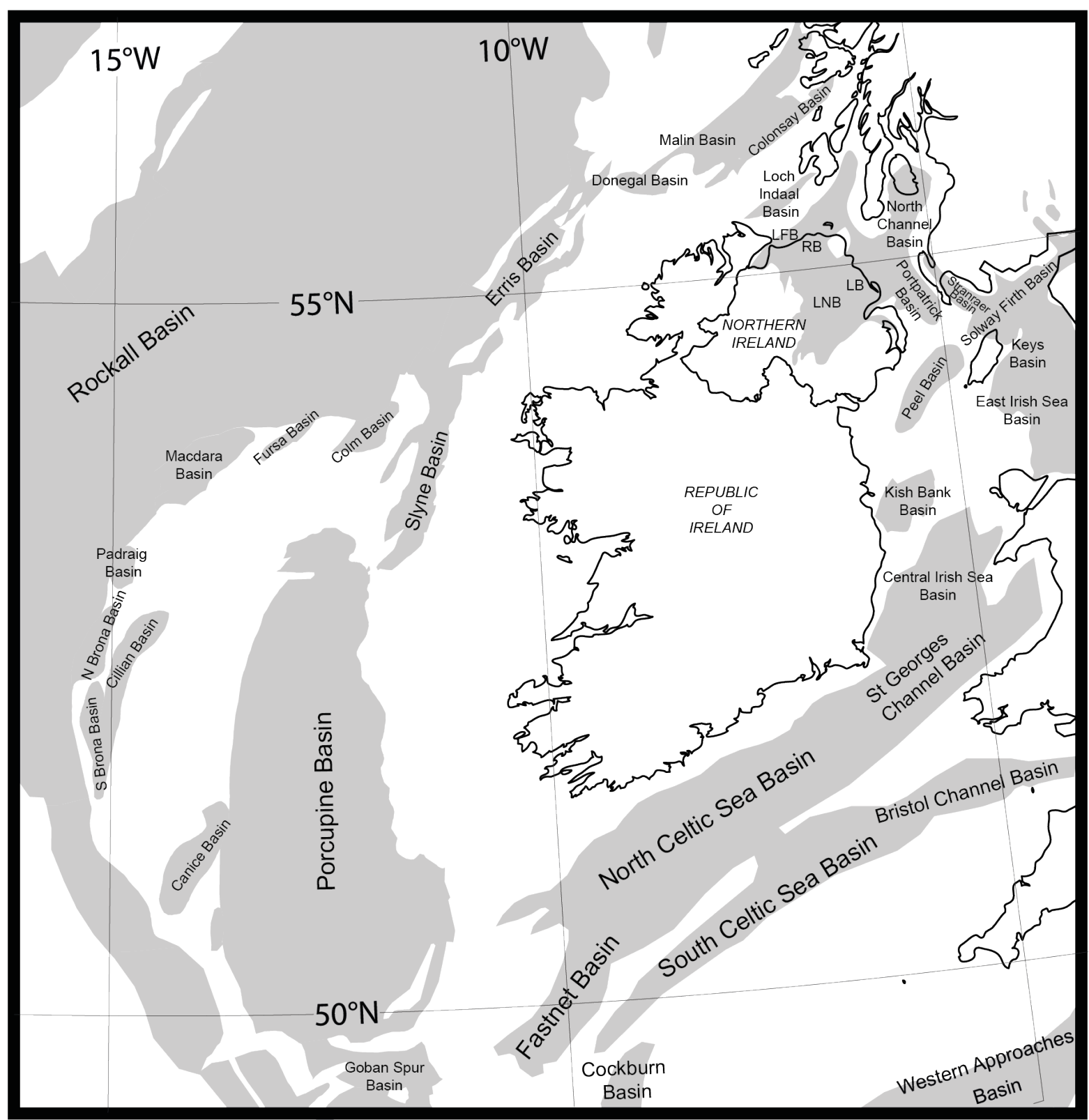

Figure 1. Location map showing the basins in and surrounding the island of Ireland. LB Larne Basin, LNB Lough Neagh Basin, RB Rathlin Basin, LFB Lough Foyle Basin. Diagram is based on offshore Republic of Ireland data from the Petroleum Affairs Division, while data on other basins is based on McClean, 1978; Fyfe et al., 1993. For a more detailed representation of the basin configuration in Northern Ireland see Figure 2. 


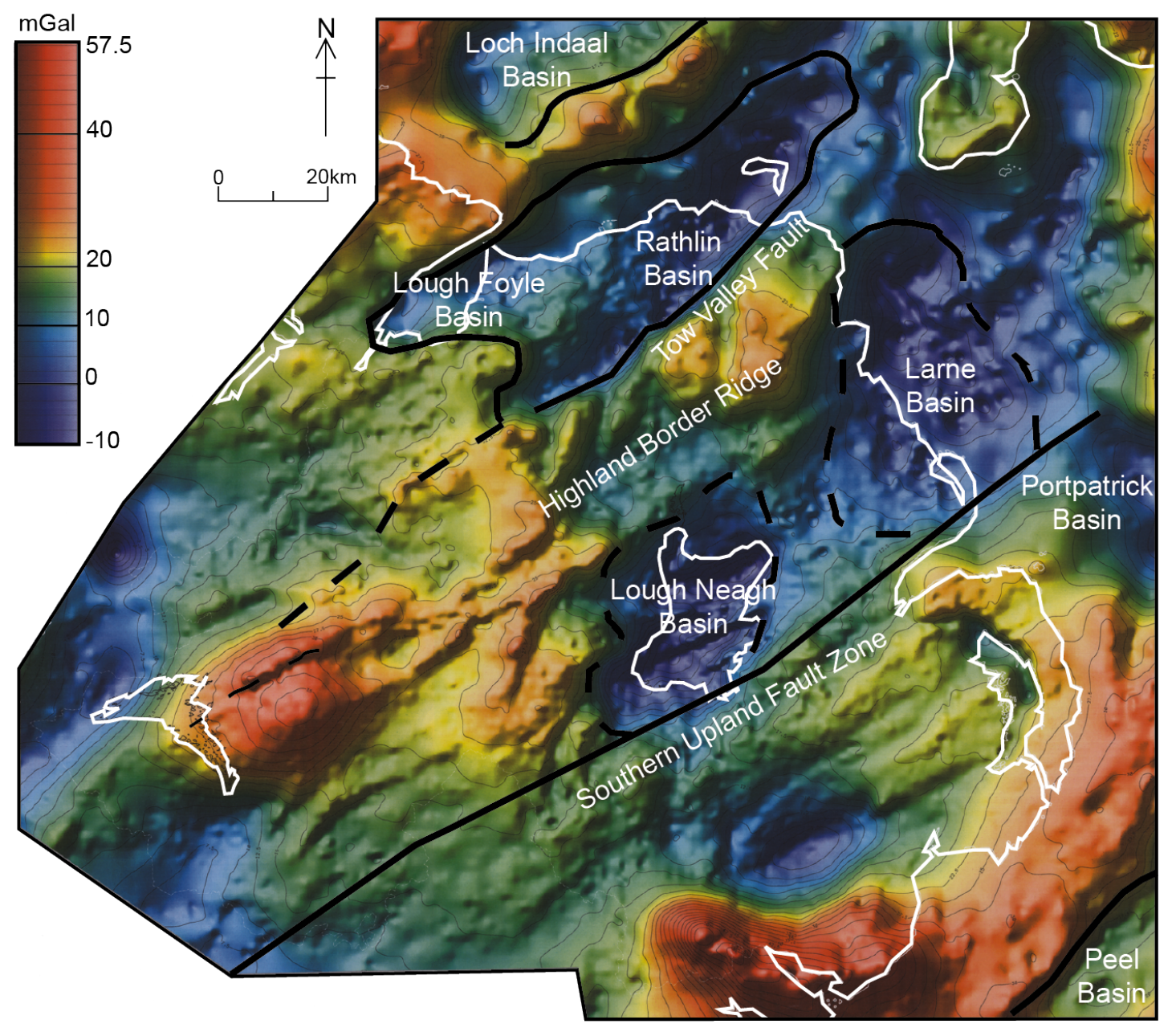

Figure 2. Bouguer gravity anomaly data covering the NE of the island and with annotations showing the location of the sedimentary basins. Colour-filled/line contours of the observed values. Shaded-relief illumination from the north-west. Amended after Carruthers et al., (1997).

In the offshore Republic of Ireland, a similar depositional style is apparent, with areas of thick Triassic sedimentation also being the locations of thick Lower (and Middle) Jurassic successions. The thickest known developments of the Lower Jurassic in offshore Ireland are in the most basinal part of the North Celtic Sea Basin area, in Quadrant 50, where more than $2134 \mathrm{~m}$ [7000 ft] of Lower Jurassic section is proven by hydrocarbon exploration wells drilled in the area. 
The preservation of Triassic and Lower-Middle Jurassic sediments in offshore Republic of Ireland basins is affected by two significant unconformities; one at the base of the Upper Jurassic (Tate and Dobson, 1989) and a further break, of large magnitude, at the base of the preserved Cretaceous. This may correlate with the 'mid and late Cimmerian events' described from Northern Ireland (Naylor et al., 2003; Green et al., 2000).

In basins to the east and south east of Ireland a further major unconformity, at the base of the Gault Formation (Late Albian), also truncates Lower Jurassic strata. This latter unconformity also has expression in southern England. These unconformities are developed extensively across offshore Ireland and are responsible for the significant truncation of Lower Jurassic strata in all offshore basins in which rocks of this age were deposited (see below for details). Each of these breaks clearly corresponds to a major structural change in the tectonic evolution of the offshore Ireland area.

\section{Basin records}

\subsection{Onshore basins}

\subsubsection{Rathlin and Lough Foyle basins}

The Rathlin and Lough Foyle basins form two opposing NE-SW trending half grabens. The Lough Foyle Basin is of more limited extent, but both basins extend offshore, and the Rathin Basin extends beneath Rathlin Island and the Malin Shelf towards the Isle of Islay and the Sound of Jura (Figure 1). The Rathlin Basin formed through regional shear and stress during the late-Palaeozoic Variscan orogeny, which reactivated the Caledonian Tow Valley Fault (Figure 2), and the ensuing normal and dextral strike-slip faulting resulted in the formation of a rift basin later filled by a succession of sediments to form the Rathlin Basin. The opposing Lough Foyle rift basin is located to the NW and stretches into County Donegal in the Republic of Ireland and is defined by downfaulting on the Foyle Fault (Figure 2). Together the basins have, in previous literature, been termed the 'Rathlin Trough' (Dobson and Evans, 1974) or Rathlin Basin (Warrington, 1997). Onshore, the basin is partially covered by Paleogene basalts, which comprise the surface geology, whereas offshore the basalts are largely absent and rocks of Triassic to Cretaceous age lie at the sea bed. 


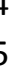

Onshore exposures of uppermost Triassic and Lower Jurassic rocks in the Rathlin Basin are scarce and comprise a few small outcrops (Figure 3), such as at Portnakillew [55 $13^{\prime} 31.0^{\prime \prime}$

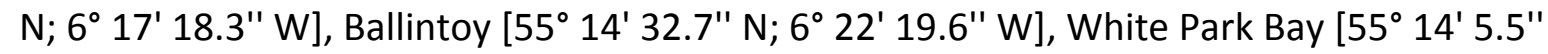

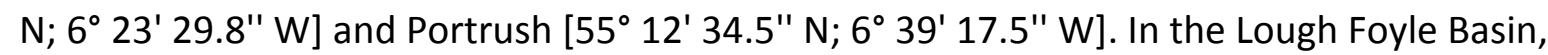
only three principal outcrop localities (Tircreven Burn [55 7' 49.6" N; 6 53' 54.7" W],

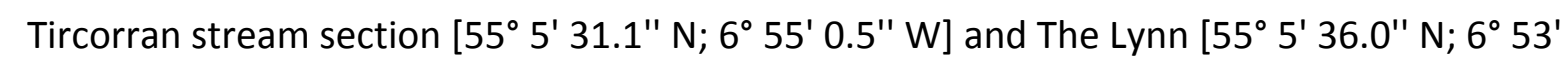
20.0" W]) expose rocks of this age (Bazley et al., 1997) (Figure 3). Subsurface records from the basins are better and include the Port More Borehole that was drilled in 1965-7 on a gravity low (Wilson and Manning, 1978) and the Ballinlea-1 well, drilled in 2008 in search of hydrocarbons in the Rathlin Basin (Boomer et al, 202X). The Lough Foyle Basin has been examined by the Magilligan Borehole (spudded 1963) and by some recent mineral exploration boreholes (Raine et al., 202X). In several locations across the basins significant dolerite and basalt sills (up to $223 \mathrm{~m}$ in thickness) have been encountered in the upper Triassic and Lower Jurassic strata, for example in the Port More (Wilson and Manning, 1978) and Magilligan (Bazley et al. 1997) boreholes and the Ballinlea-1 well. Bazley et al. (1997) estimated a maximum thickness of $180 \mathrm{~m}$ of Jurassic sediments in the Lough Foyle Basin by combining the thickness in the Magilligan Borehole of $74 \mathrm{~m}$ and $52 \mathrm{~m}$ in the Tircreven Burn section. 


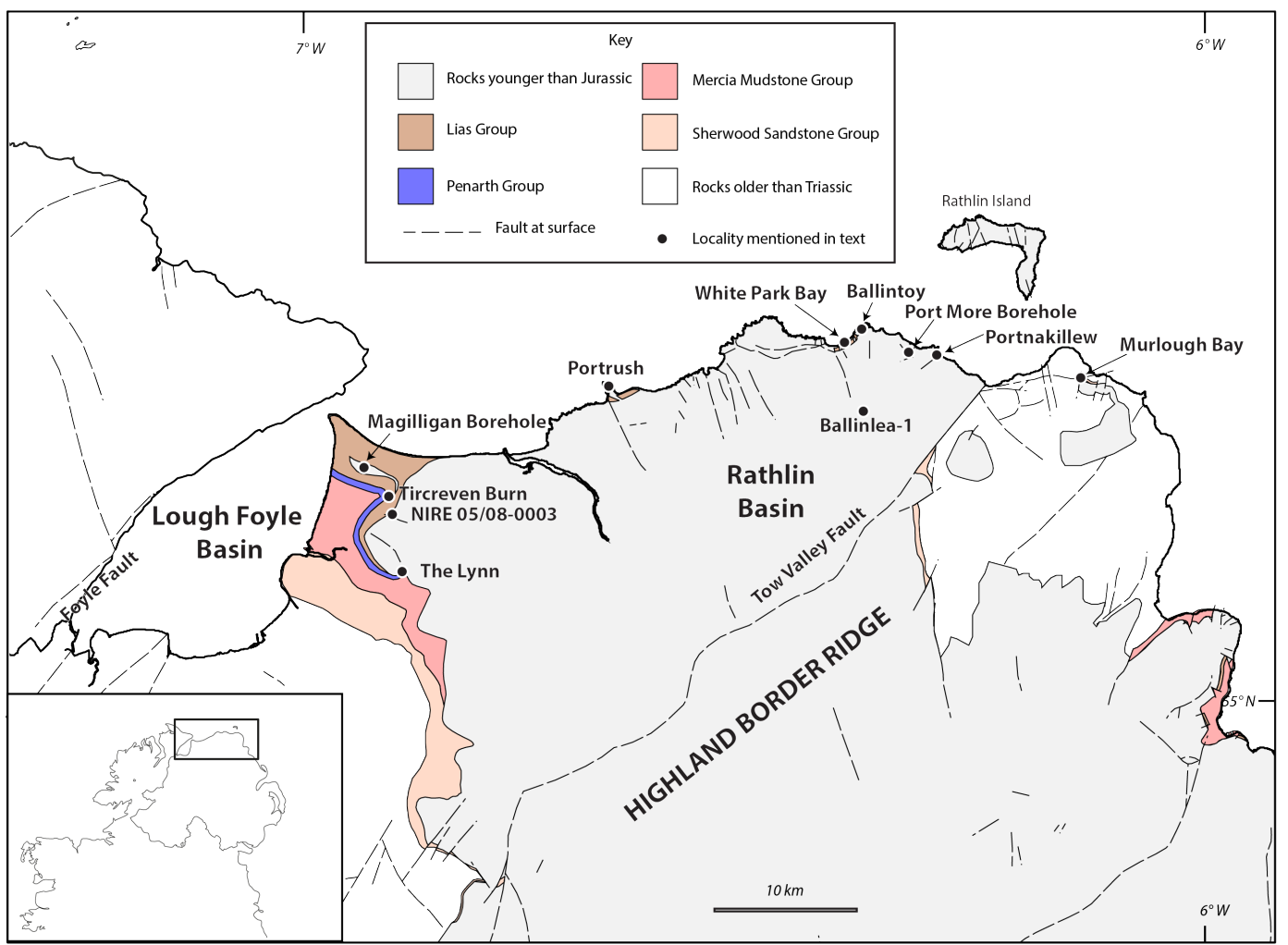

Figure 3. Map showing the area of the Rathlin and Lough Foyle basins and the distribution of

Triassic and Jurassic rocks at surface. The locations and boreholes mentioned in the text are shown. The outcrop width of the Penarth Group has been exaggerated slightly. Based on Geological Survey of Northern Ireland (1997).

\subsubsection{Larne Basin}

The Larne Basin (Figures 1 and 2) lies in the Midland Valley terrane that stretches from SW Scotland across to Northern Ireland, with a large part of the basin located offshore in the North Channel between Northern Ireland and Scotland. The basin is oriented NE-SW and the thickness of Carboniferous to Cenozoic strata increases westward. Onshore, the basin is divided by the NE-SW-trending Sixmilewater Fault. Extension that was oriented ENE-WSW was followed in the Late Triassic and Early Jurassic with post-Early Jurassic to Late Cretaceous minor subsidence and uplift, resulting in a major erosional unconformity between the Lower Jurassic Waterloo Mudstone Formation and the Upper Cretaceous Hibernian Greensand Formation and Ulster White Limestone Formation (Shelton, 1997). 
uppermost Triassic and Lower Jurassic strata are found throughout the basin and were initially described by Tate (1867), who focused on the Waterloo Bay [ $54^{\circ} 51^{\prime} 37^{\prime \prime} \mathrm{N}, 5^{\circ} 48^{\prime}$ 23 " W] foreshore section at Larne (Figure 4). Later, that section together with a number of smaller localities in the basin were described more fully by Ivimey-Cook (1975) and the nearby 1962-3 Larne No.1 Borehole by Manning and Wilson (1975). There have subsequently been a number of other deep boreholes in the basin, Larne No.2 (which commenced in the Mercia Mudstone Group), Ballytober No. 1 (encountered the Lias Group but recorded no Penarth Group), Cairncastle No. 2 (recorded both Lias Group and Penarth Group and cored the upper part of the Lias Group), Carnduff No. 1 and Carnduff No. 2 cored the Lias and Penarth groups in full. At outcrop at Waterloo Bay, Larne, the Upper Triassic and Lower Jurassic rocks are well exposed (Simms and Jeram, 2007).

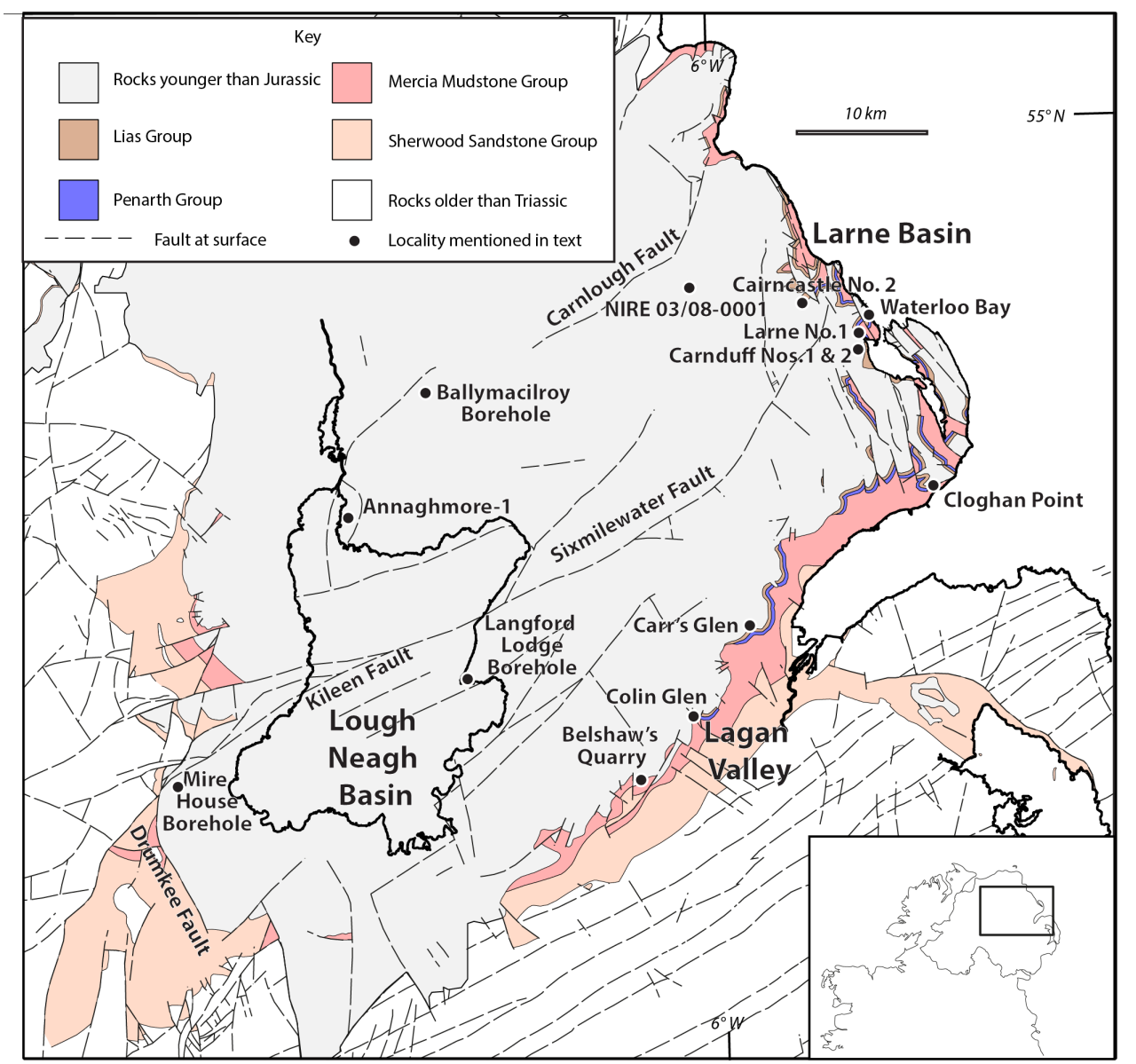

Figure 4. Map showing the distribution of Triassic and Jurassic rocks across the Lough Neagh and Larne basins and into the present day Lagan Valley area. The outcrop localities and 
borehole/well locations that are discussed in the text are shown. The thickness of the Penarth and Lias groups are exaggerated on the map to make them more visible. Based on Geological Survey of Northern Ireland (1997).

\subsubsection{Present day Lagan Valley area}

Between the Larne and Lough Neagh basins is the present-day Lagan Valley (Figure 4), bordered to the south by the Ordovician and Silurian low-grade metasediments of the Down-Longford Massif. The Upper Triassic and Lower Jurassic are intermittently preserved beneath the Cretaceous rocks along the Lagan Valley at the margins of the Antrim Plateau, for example at Colin Glen [ $54^{\circ} 34^{\prime} 46.4^{\prime \prime} \mathrm{N}, 6^{\circ} 2^{\prime} 10.9^{\prime \prime} \mathrm{W}$ ] and Carr's Glen [54 $35^{\prime} 38.0^{\prime \prime} \mathrm{N}$, $5^{\circ} 57^{\prime} 54.3^{\prime \prime} \mathrm{W}$ ] (Figure 4). Only a few tens of metres are preserved at most but some stream sections expose both the uppermost Triassic and the Lower Jurassic. Early literature described the sections in and around the vicinity of Belfast at Colin Glen (the type section for the differently spelled Collin Glen Formation) and other small exposures (Tate, 1864; Lamplugh et al., 1904). Other sections, such as at Belshaw's Quarry [54 $32^{\prime} 14.9^{\prime \prime} \mathrm{N}, 6^{\circ} 6^{\prime}$ 6.3" W] show the Ulster White Limestone (Cretaceous) resting on the Mercia Mudstone Group.

\subsubsection{Lough Neagh Basin}

The Lough Neagh Basin is the deepest of the Permo-Triassic basins in Northern Ireland (Figure 2). The lough itself has restricted the collection of seismic profiles and drilling and hence most, of our knowledge on the structure of this basin has come from gravity data and a few deep boreholes around the margins of the lough (Figure 4). In the basin, Upper Triassic and Lower Jurassic sediments are largely concealed by Cretaceous limestones, Paleogene basalts, and Oligocene claystones and lignites. The asymmetric form of the basin is structurally controlled along its southern flank by northeast-southwest trending faults and resembles the southern part of the Rathlin Basin. Gravity modelling (Carruthers et al., 1997) predicted a total basin depth of almost $4 \mathrm{~km}$. The stratigraphy of the basin has been tested in the Ballymacilroy and Langford Lodge boreholes, which both encountered Upper 
Triassic and/or Lower Jurassic rocks. Much of the Upper Triassic and Lower Jurassic strata in this basin have been removed along the basin margin and so its thickness and distribution in the subsurface is poorly understood.

At the basin margin the Cretaceous strata rest directly on the Mercia Mudstone and Sherwood Sandstone groups and there is no outcrop of the Lias Group. In the subsurface, towards the south west margin of the basin, the Mire House Borehole penetrated $134.72 \mathrm{~m}$ of Upper Triassic and Lower Jurassic strata (Fowler et al., 1961). Mire House was drilled in a gravity low, bounded to the west by the $\mathrm{N}-\mathrm{S}$ trending Drumkee Fault and to the north by the ENE-WSW Kileen Fault, so it is conceivable that other thick successions may be preserved where there has not been Jurassic-Cretaceous uplift. The presence in the Mire House Borehole of a relatively thick Jurassic succession so close to the current basin margin suggests that Jurassic strata once extended beyond the main basin bounding faults. On the eastern margin of the basin the Langford Lodge Borehole, drilled on a fault-bounded interbasinal high, proved only $26.6 \mathrm{~m}$ of uppermost Triassic and Lower Jurassic. No other deep boreholes in the basin encountered Upper Triassic and Lower Jurassic rocks except for the Ballymacilroy Borehole, in the northern part of the basin, which proved $151 \mathrm{~m}$ of Jurassic (Thompson, 1979). Approximately $11 \mathrm{~km}$ to the south-west, on a structural high, Late Triassic to Early Jurassic sediments were absent in the Annaghmore No. 1 and Ballynamullan No. 1 wells due to erosion prior to the Late Cretaceous "late Cimmerian unconformity" (Naylor et al., 2003).

\subsection{Offshore basins}

\subsubsection{Loch Indaal Basin}

The Loch Indaal Basin (Figure 2), a half graben, contains NW-dipping Permo-Triassic rocks capped by an unknown thickness of Jurassic rocks. In total there may be up to $2.5 \mathrm{~km}$ of sediment in the basin (Evans et al., 1980; Fyfe et al., 1993). Uppermost Triassic and Lower Jurassic sediments were proven in the Loch Indaal Basin by shallow boreholes 75/41, 75/44 
(Evans et al., 1980; Warrington 1997). The borehole 75/41 encountered $12.57 \mathrm{~m}$ of Penarth Group (Fyfe et al., 1993). Borehole 75/44 penetrated 15.15 m of Lias Group sediments.

\subsubsection{Offshore Rathlin, Lough Foyle and Larne basins}

There is little information on the offshore parts of these basins (Figure 2). There are some seismic lines that might allow the structure to be evaluated, but only a few shallow cores have been collected. The seabed across most of the offshore part the Larne basin is of Triassic strata but one of us [IB] has recovered an Early Jurassic (Pliensbachian) calcareous microfossil assemblage of ostracods and foraminifera from a BGS seabed sample just $5 \mathrm{~km}$ to the NW of Rathlin Island (Figure 3) demonstrating that Jurassic sediments outcrop in some of this offshore region.

\subsubsection{Kish Bank Basin}

The Kish Bank Basin was primarily a Palaeozoic (Carboniferous) to Triassic (Sherwood Sandstone and Mercia Mudstone groups) depocentre (Naylor et al., 1993; Dunford et al., 2001). Lias Group sediments are proven only in a sea-bed sample (Dobson and Whittington, 1979); however, the precise age of these sediments is poorly constrained.

\subsubsection{Central Irish Sea Basin}

At least 66 m of Lias Group siltstones and claystones, of Hettangian age, are present in the Central Irish Sea Basin above thick Palaeozoic and Triassic successions (Maddox et al., 1995; Maingarm et al., 1999). Studies of apatite fission track (AFTA) and vitrinite reflectance (VR) by Green et al., (2001) have shown however, that the basin experienced a palaeo-thermal episode in the Late Jurassic - Early Cretaceous, suggesting burial under approximately three kilometres of additional section. These strata were then subsequently removed by uplift and erosion since the Early Cretaceous (Green et al., 2001).

\subsubsection{Celtic Sea basins}


The North Celtic Sea Basin is structurally linked to the Fastnet Basin to the west and to the St. George's Channel, Cardigan Bay, South Celtic Sea and Bristol Channel basins to the east. These form a series of linked rift basins that extend from the offshore Ireland waters east of Ireland into the western offshore UK area. The basins in the Celtic Sea are elongate Mesozoic extensional basins with a general ENE-WSW orientation that were subject to multiple phases of rifting (Early Triassic, Early Jurassic, Late Jurassic and Early Cretaceous) and inversion (Early Palaeogene and Neogene) (Hernon et al., 2017). The North Celtic Sea Basin is separated from the South Celtic Sea Basin by the Labadie Bank - Pembrokeshire Ridge basement highs.

The tectonic and sedimentary history of the area through the Mesozoic is closely related to the staged opening of the North Atlantic. The Celtic Sea basins show gross similarities to other North Atlantic basins in orientation and timing of development. Three discrete phases of extension and fault-controlled subsidence can be recognized since the basin was formed in the Permian, although timings of these phases vary between authors (Rowell, 1995; Byrne, 2015; Hernon et al., 2017).

\section{More than 2000 m of Penarth Group and Lias Group strata are proven from the many} hydrocarbon exploration wells that have been drilled in the Celtic Sea basins, with the thickest developments of the Lower Jurassic in offshore Ireland in the northern part of the basin, in Quadrant 50. Wells 50/3-1 and 50/3-3, drilled by Marathon in 1976 and 1991 respectively, proved a total of more than $2134 \mathrm{~m}$ (7000 ft) of Lower Jurassic section. Furthermore, by extrapolating from these wells onto seismic data an even deeper and thicker, as yet undrilled, area of Lower Jurassic deposition can be inferred nearby in the deepest part of this basin (see Kessler and Sachs, 1995) to the west of the UK 103/1-1 Dragon gas discovery well.

Copestake et al. (2017) illustrated a seismic line across this area and estimated a possible thickness of around $3000 \mathrm{~m}$ of Lower Jurassic in this basin on the basis of extrapolation from 
wells such as 42/21-1 and UK 103/1-1. Kessler and Sachs (1995) described the Lower Jurassic succession in the northern part of the basin, focusing on the 50/3-1 and 50/3-3 wells, and illustrated the development of two significant shallow marine sandstones, the Upper Sinemurian Sandstone and Lower Sinemurian Sandstone. These correlate with sandstones of the same age that are developed in the Fastnet Basin (see below). These sandstones are overlain by a thick development of Pliensbachian and Toarcian-Aalenian claystones and mudstones in this area. The Lower Jurassic section in these two wells was illustrated also by Copestake et al. (2017) and correlated with two wells from the Slyne Basin, 27/4-1 and 18/20-1, based on recognition of a succession of depositional sequences (J sequences of Partington et al., 1993) across the Republic of Ireland offshore area. The Penarth Group was recognised in the Celtic Sea area by Shannon (1995) and was subdivided by him into a 'Lower Marl Member' and an overlying 'Upper Limestone Member'.

\subsubsection{Fastnet Basin}

The Fastnet Basin, originally defined by Robinson et al. (1981) is a narrow elongate Mesozoic extensional basin that is genetically related and connected to the North Celtic Sea Basin. It contains considerable thicknesses of Triassic and Jurassic strata, although significantly affected by the erosional effects of the Berriasian (Base Cretaceous) unconformity.

Murphy and Ainsworth (1991) defined an informal lithostratigraphy for the Triassic and Lower to Middle Jurassic (Aalenian) of the Fastnet Basin. For the Lower Jurassic these are, in ascending order, the Basal Liassic Claystone, Liassic Limestone Unit and Liassic Marl Unit, which span the Hettangian to earliest Sinemurian. These are overlain by the Liassic Sandstone Unit, of Sinemurian age, which is succeeded by the Liassic Shale Unit that spans the Pliensbachian to Aalenian interval. Reference wells for these units included the 56/21-1, 56/21-2 and 63/10-1 hydrocarbon exploration wells. The Liassic Limestone Unit represents alternating continental (freshwater to brackish water) to marine inner shelf environments (Murphy and Ainsworth, 1991). The development of marginal marine palaeoenvironments in the Fastnet Basin during the Hettangian represents a significant departure from the usual fully marine environments of the Early Jurassic in the region and shows depositional 
similarities with the Hettangian - Lower Sinemurian succession in the Slyne Basin (see below).

The Liassic Limestone Unit generates a strong seismic reflector and can be used for mapping in the area (Robinson et al., 1981). The Liassic Sandstone Unit correlates with the Upper and Lower Sinemurian Sandstones developed in the North Celtic Sea Basin, Quadrant 50 (see above) (Ewins and Shannon, 1995).

\subsubsection{Cockburn Basin}

The Cockburn Basin is another in the series of sub-parallel basins in the Celtic Sea-Western Approaches area and lies to the southwest of the Fastnet Basin. No wells or boreholes have been drilled in the basin but, based on seismic correlation, a very similar stratigraphic succession to that of the Fastnet Basin is assumed to be present as well as a major baseCretaceous (Berriasian) unconformity that truncates the Jurassic succession (Smith, 1995).

\subsubsection{Goban Spur Basin}

A Lower Jurassic (Hettangian-Toarcian) succession totalling $1220 \mathrm{~m}$ in thickness was proved in the only well yet drilled in the basin, 62/7-1. The stratigraphic succession is very similar to that of the Fastnet Basin and is largely claystone dominated. It terminated in Hettangian strata and thus the Triassic section in the basin is unknown, although the basin is believed to have been initiated during the Triassic (Colin et al., 1992).

\subsubsection{Porcupine Basin}

The Porcupine Basin lies adjacent to the continental margin of north-west Europe and is the most westerly of a series of north-south rift basins that includes the Viking Graben in the North Sea (Croker and Klemperer, 1989). Major rifting took place during the Late Jurassic but Lower Jurassic and Triassic sediments are proven by wells drilled in the northern part of the basin, $26 / 21-1$ and $26 / 22-1 \mathrm{~A}$, although the section here is severely truncated by an 
unconformity beneath the Upper Jurassic (Croker and Klemperer, 1989). Lower Jurassic strata are probably present further south in the main part of the basin (Johnston et al., 2001) although this has not yet been proven by drilling.

\subsubsection{Slyne Basin}

The Slyne Basin comprises a narrow, elongate, SW-NE orientated basin north east of the Porcupine Basin that was formed in Permian-Late Jurassic times and contains up to $600 \mathrm{~m}$ of Lower Jurassic strata (Stoker et al., 2017). The stratigraphic succession is well known from hydrocarbon exploration and development wells, including those of the Corrib Gas Field, blocks 18/20 and 18/25 (see Dancer et al., 1999, 2005). Several wells penetrated thick Triassic and Lower Jurassic successions (e.g. Trueblood, 1992, Dancer et al., 1999, 2005 and Pritchard, 2016). Comparisons have been made between the Lower Jurassic successions in the Slyne Basin and the Hebrides Basin, on the isles of Skye and Raasay, western Scotland (discussed in Section 5).

\subsubsection{Erris Basin}

The Erris Basin is a narrow elongate, Mesozoic basin that lies adjacent to the eastern margin of the Rockall Basin northwest of Ireland. There has been limited drilling in these basins, but the $12 / 13-1 A$ and $19 / 5-1$ hydrocarbon exploration wells have proved Carboniferous, PermoTriassic, Lower Jurassic and Cretaceous sediments beneath a Cenozoic cover (Tate and Dobson, 1989; Chapman et al., 1999). The Lower Jurassic section is incomplete, representing only parts of the Sinemurian and Hettangian stages in argillaceous dominated lithofacies, with the section truncated by the Base Cretaceous Unconformity (Chapman et al. 1999; Stoker et al., 2017).

\section{Chronostratigraphy}

The chronostratigraphy of these basins is based largely upon ammonite stratigraphy, particularly in onshore outcrop sections, but chronostratigraphic and biostratigraphic age interpretations are based on microfossil biostratigraphy in the extensive offshore basins and 
in some wells drilled onshore (such as Ballinlea-1, Boomer et al., 202X). Ammonites are not recovered in non-cored hydrocarbon exploration wells due to destruction of large macrofossils by the drilling process but a refined biostratigraphic scheme has been developed (e.g. Ainsworth et al., 1987, 1989), based on foraminifera, ostracods and occasional dinoflagellate cysts. A recent major review of the stratigraphy of offshore Ireland will incorporate newly defined microfossil based biozonation schemes for the Late Triassic to Early Jurassic interval (Merlin, in prep.).

Ammonite stratigraphy has been published for some deep boreholes, with the most comprehensive from the Magilligan (Bazley et al., 1997), Port More (Wilson and Manning, 1978), Mire House (Fowleret al., 1961) and Larne No. 1 boreholes (Manning and Wilson, 1975). Discussion of outcrop ammonite records was presented by Warrington (1997).

The Rhaetian is present beneath most Jurassic sections. Jurassic strata in Northern Ireland range from Hettangian to Pliensbachian in age, although most sections preserve only the lower Hettangian and only on the north Antrim coast and in boreholes in the Rathlin Basin are strata as young as the Pliensbachian preserved (Figure 5). Younger strata are seemingly absent from Northern Ireland although derived fossils in a conglomerate at the base of the Cretaceous across the Highland Border Ridge indicate strata as young as Toarcian may once have been present.

Clasts with Upper Pliensbachian fossils have been historically reported in the glacial deposits near Ballycastle (Langtry, 1875; Gray, 1870) and Ballintoy (Tate, 1870). These reportedly resemble the Scalpay Sandstone Formation of Skye and Raasay (Inner Hebrides, Scotland) and from the block at Ballintoy a rich assemblage of fossils was obtained (Wilson and Robbie, 1966). Hartley (1933) and Savage (1963) recorded Toarcian ammonites from the basal Cretaceous conglomerate at Murlough Bay and Versey (1958) and Wilson and Robbie (1966) later recorded upper Pliensbachian ammonites from the same bed, suggesting that a more full succession of Jurassic was present in the vicinity prior to or during progradation of the Cretaceous shoreline sediments. More extensive successions are developed offshore, 
spanning the entire Early Jurassic interval from the Hettangian to Toarcian and ranging upwards into the Middle Jurassic.

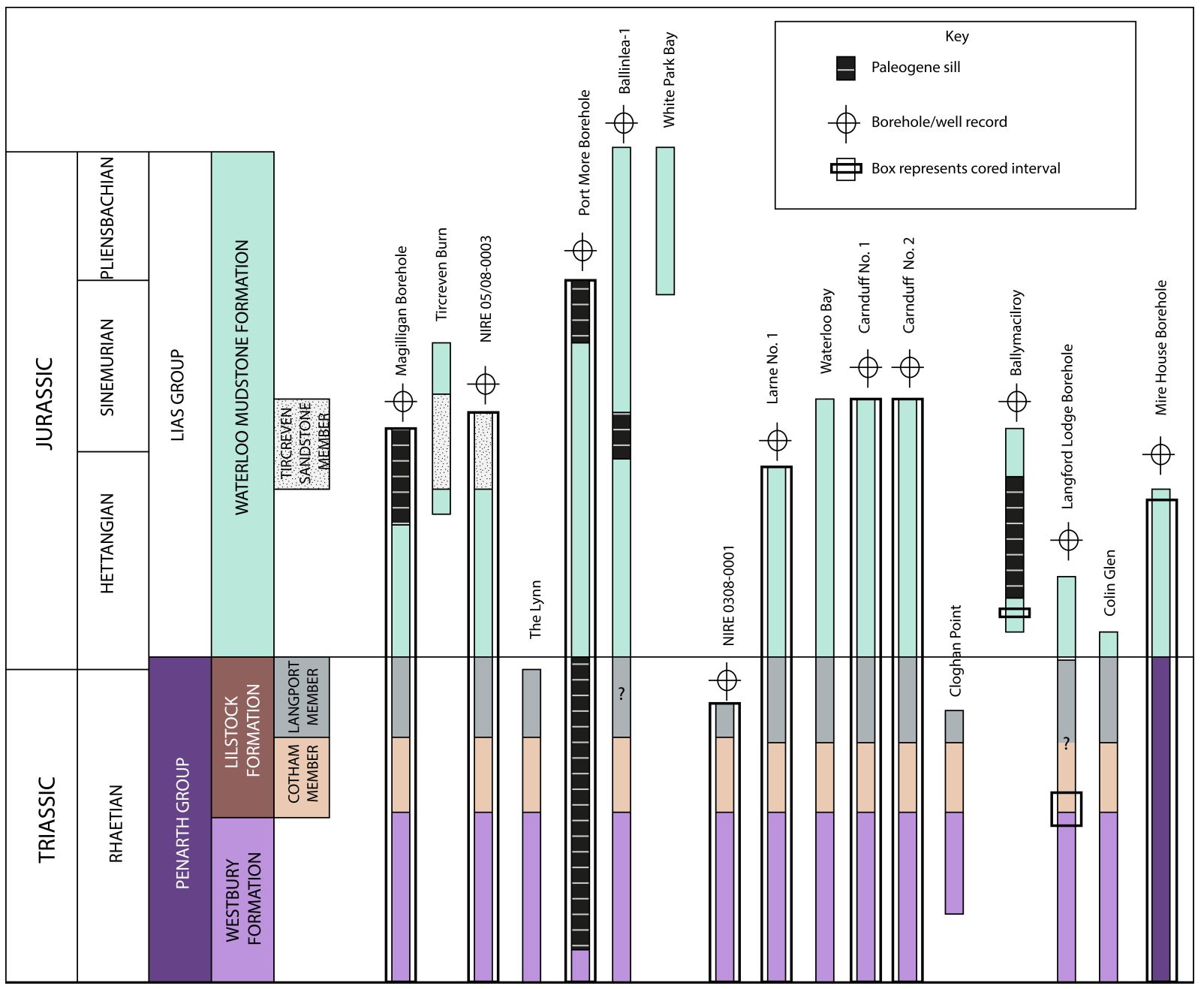

Figure 5. The chronostratigraphy of outcrops, boreholes and exploration wells from onshore basins in Northern Ireland showing the age of the sediments encountered.

\section{Lithostratigraphy of the Penarth Group}

The broad two-fold subdivision of the Penarth Group into the Westbury Formation and the Lilstock Formation, as originally defined in southern England and South Wales (Warrington et al., 1980) is also applicable in Northern Ireland and to offshore areas around the island of Ireland. 
Historically, Portlock (1843) described some Late Triassic fossils from Northern Ireland, including the iconic Rhaetian bivalve Rhaetivicula contorta (Portlock), referring to strata that are now included in the Penarth Group, but it was not until the work of Tate (1864) that these strata were placed in the 'Rhaetic', encompassing his 'Avicula contorta shales' and overlying 'White Lias'. They continued to be termed 'Rhaetic' although it was alluded to by some authors that they could be correlated with the Westbury and the Lilstock formations elsewhere. Manning et al. (1970) used the divisions of 'Lower Rhaetic' and 'Upper Rhaetic' (terms that are now obsolete) for these sediments in the Belfast and Lagan Valley area.

The Penarth Group around Limavady, Co. Londonderry, was also divided into lower and upper 'Rhaetic' by Bazley et al. (1997) who identified a 'Lower Rhaetic' contorta Zone comprising dark grey mudstones thin limestones and siltstones, equivalent to the Westbury Formation, and an 'Upper Rhaetic' comprising reddish brown and pale grey calcareous mudstones attributed to the 'Cotham Beds' overlain by grey mudstones and limestones assigned to the 'Langport Beds'.

The Penarth Group is a thin but persistent unit, and remarkably constant in thickness. It ranges in thickness from $20.55 \mathrm{~m}$ in the Larne No. 1 Borehole (Larne Basin) to $21.64 \mathrm{~m}$ in the Magilligan Borehole (Lough Foyle Basin), 23.00 m (based on log response and cuttings description) in the Ballinlea-1 well (Rathlin Basin) and $20.31 \mathrm{~m}$ in the NIRE 05/08-0003 Borehole. In the Lough Neagh Basin the Penarth Group is possibly represented by $9.75 \mathrm{~m}$ of marginal facies in the Mire House Borehole (Fowler et al., 1961). Although a thin unit, these records from Northern Ireland are thicker than those from SW Britain, but comparable in thickness to parts of the East Midlands (Bridge et al., 1998 p. 93; Old et al., 1987 p.30).

In some borehole records it is not possible to differentiate individual units within the Penarth Group or assign them to the established lithostratigraphy. In the Mire House Borehole a unit between the Mercia Mudstone Group and the Lias Group may be an equivalent of part or all the Penarth Group, comprising $4.72 \mathrm{~m}$ of dark greenish grey soft 
and clayey or hard fissile mudstones above $5.03 \mathrm{~m}$ of grey-green mudstones with quartz granules/pebbles and nodules of light grey-pink limestone (Fowler et al., 1961). This rests on red and grey mottled calcareous claystones and red-brown marls attributed to the Mercia Mudstone Group. The grey-green rocks of the Penarth Group resemble the Collin Glen Formation, although it was noted that there may have been a disconformity at the top of the Mercia Mudstone Group. The presence of anhydrite in the Mercia Mudstone Group may suggest erosion down to a lower stratigraphical position and the erosion of the Collin Glen Formation, typically a green grey mudrock, might explain the resulting colour of the Penarth Group claystones. Eotrapezium ewaldi (Bornemann) at $746.76 \mathrm{~m}$ depth and Gyrolepis sp. from $777.01 \mathrm{~m}$ depth confirm a Rhaetian age and suggest correlation with the Penarth Group. No black shales are recognised in this succession but fossils within these facies suggest that the unit is a lateral equivalent of at least part of the Penarth Group.

The Langford Lodge Borehole (Manning et al., 1970) was drilled in the east of the Lough Neagh Basin with very limited core recovery (just 1.0 m between 821.13-823.27 m). Perhaps $17.38 \mathrm{~m}$ of strata represent the Penarth Group but identifying individual units is difficult and there are discrepancies between the position of boundaries defined by wireline logs, which suggest the top is $4.5 \mathrm{~m}$ lower than indicated by cuttings, and gamma logs that suggest the base may be $3.05 \mathrm{~m}$ higher than indicated by cuttings (Manning et al., 1970). In the Langford Lodge Borehole the base of the Cotham Member is possibly at $822.3 \mathrm{~m}$ and the boundary between the Westbury Formation and the overlying Cotham Member lies within the cored section suggesting a thickness of $6.05 \mathrm{~m}$ for the undifferentiated Langport and Cotham members, which includes grey to grey brown, sometimes micaceous, shales and shaley mudstone with Eotrapezium ewaldi and Modiolus langportensis (Richardson and Tutcher), and $11.33 \mathrm{~m}$ for the Westbury Formation, represented by black shales with Eotrapezium concentricum? Protocardia rhaetica (Merian) and R. contorta.

Strata assigned to the Penarth Group occur widely in offshore Irish basins but are poorly documented. The group was identified in the Celtic Sea area by Shannon (1995) and subdivided into a 'Lower Marl Member', which he correlated with the 'Rhaetian Marl Unit' 
of Murphy and Ainsworth (1991) in the Fastnet Basin (see below), and an overlying 'Upper Limestone Member'. It is possible, however, that the 'Rhaetian Marl Unit' includes all or part of the Blue Anchor Formation of standard British Triassic nomenclature.

The Penarth Group is also present in several offshore basins that connect Ireland and the UK onshore areas, namely the Bristol Channel, St George's Channel and South Celtic Sea basins, suggesting contiguous deposition between these areas (see data in Tappin et al., 1994). In the Corrib Field area (Block 18/20, Slyne Basin) Schmidt et al. (2006) included sediments that appear to be representative of the Penarth Group in the upper part of their Mercia Mudstone Group.

\subsection{Westbury Formation}

The Westbury Formation is the lowest formation of the Penarth Group and, in many localities, overlies the green and red non-marine mudrocks of the Mercia Mudstone Group (Collin Glen Formation) with a sharp and erosive to somewhat gradational boundary. In some cores (Magilligan and Carnduff No. 2 boreholes) black mudstone has been injected along fractures in the underlying Collin Glen Formation. The unconformable break at the base of the Penarth Group (Westbury Formation) is comparable with that at the base of the group in south west Britain (Wilson et al., 1990; Howard et al., 2008; Gallois, 2009).

The top of the formation is marked by a change from black shales to light grey mudstones of the Lilstock Formation (Cotham Member). This boundary is commonly sharp, irregular and deformed, with clasts of Westbury Formation facies and fossils admixed with the Cotham Member facies.

In the Lough Neagh Basin the Westbury Formation was encountered only in the Langford Lodge Borehole. It may be $11.30 \mathrm{~m}$ thick here although this may be a less accurate figure than from other boreholes due to uncertainty in the cuttings and wireline picks. 
570 One complete section has been recorded in the Lagan Valley area at Colin Glen, towards the margin of the Larne Basin, where there is probably $6.02 \mathrm{~m}$ of the Westbury Formation (Tate, 1864). Further east and north in the Larne Basin there are many more records of the Westbury Formation, such as the Carnduff No. 2 Borehole (7.73 m), the NIRE 03/08-0001 Borehole $(7.17 \mathrm{~m})$, the Waterloo Bay foreshore at Larne $(7.29 \mathrm{~m})$, and the Larne No. 1 Borehole $(8.28 \mathrm{~m})$. In the Lough Foyle Basin $7.92 \mathrm{~m}$ is recorded in the Magilligan Borehole, $6.38 \mathrm{~m}$ in the NIRE 05/08-0003 Borehole and at least $7.96 \mathrm{~m}$ at The Lynn. The only record from the Rathlin Basin is the Port More Borehole (660.70 to $664.77 \mathrm{~m}$ ) but the upper part of the Westbury Formation here is obscured by a sill, below which only $4.07 \mathrm{~m}$ of the formation were cored with up to a further $1.22 \mathrm{~m}$ (the underlying uncored interval). Outcrop and borehole data from separate basins across Northern Ireland suggest that the Westbury Formation transgression was widespread across the area and sedimentation rates were relatively uniform.

Facies that comprise the Westbury Formation in Northern Ireland are similar to those across the rest of the UK, dominated by dark grey to black laminated claystones with subordinate siltstones, sandstones, sandy limestones and beds with low diversity shell accumulations. Chlamys valoniensis dominates in the sandstones, Protocardia rhaetica in the mudstones and Rhaetavicula contorta in the shales (Boomer et al., 202Xb). Bioturbation is intense in the more silty and sandy intervals and at Waterloo Bay, Larne, comprises Diplocraterion, Arenicolites, Rhizocorallium, Lockeia, Planolites, Cruziana and Teichichnus (Boomer et al., $202 \mathrm{Xb}$ ). Mudstones are generally well-laminated. Fish debris is common but no coarse bone beds containing reptile remains have been found comparable with those in the Westbury Formation of the Bristol Channel Basin.

\subsection{Lilstock Formation}

Although generally richer in clastic material than elsewhere in the UK the Lilstock Formation in Northern Ireland can be similarly subdivided into two component members. Its position above the distinctive Westbury Formation and the presence of hiatus surfaces, soft sediment deformation and rare stromatolites allow correlation with the Cotham and 
Langport members in Great Britain and hence the names are retained here. The division is primarily one where the boundary between the Cotham Member and the overlying Langport Member is gradational, but marked by a deepening of facies and an increase in bivalve diversity and carbonate content, reflecting a more open marine setting.

The Lilstock Formation is recognised across Northern Ireland but it varies in thickness and facies. In some recent papers the Cotham and Langport members in southwest Great Britain have been elevated to formation status (Gallois, 2008), but this has not been done here. In early research the strata above the black shales (Westbury Formation) and below the Waterloo Mudstone Formation, seen at Colin Glen in the Lagan Valley, was assigned by Tate (1864) to the 'White Lias'. Manning et al. (1970) termed it the 'Upper Rhaetic', as did Ivimey-Cook (1975), and only later were they equated with the 'Cotham Beds' by Thompson (1997) and by Bazley et al. (1997).

\subsubsection{Cotham Member}

Although the lower boundary is sharp, the injection and mixing of Westbury Formation facies and their similar bivalve fauna suggests that there is little time gap and it is therefore largely conformable. In the lower part of the Cotham Member in NIRE 0308-0001 there are lower decimetre-scale alternations of very dark grey and light grey mudstone. Deformation of the boundary is not seen in core, but it is exceptionally well demonstrated at Cloghan Point [ $54^{\circ} 44^{\prime} 34.1^{\prime \prime}, 5^{\circ} 43^{\prime} 6.2^{\prime \prime} \mathrm{W}$ ]. Identification of the Rhaetian bivalve $R$. contorta in the lowest beds of the Cotham Member (Bazley et al. 1997; Manning et al, 1970) seems to support that the lower Cotham Member is of similar age to the top of the Westbury Formation in Northern Ireland. The base of the member is readily correlated with sections in Great Britain, where dark shales are fairly abruptly succeeded by paler mudstones with softsediment deformation.

\footnotetext{
The upper boundary of the Cotham Member is gradational and taken at a change from rippled siltstone-claystone heteroliths, with or without carbonate, to a darker more clay
} 
dominated succession, at least initially, that locally contains diagenetic carbonate beds (Simms and Jeram, 2007). Simms (2003) incorrectly assigned the upper part of the Cotham Member to the Lias Group but subsequently (Simms, 2007) revised the lithostratigraphy, extending the top of the Cotham Member upwards and distinguishing a lower and upper Cotham Member with the boundary at the mudcracked surface $(4.80 \mathrm{~m}$ above the top of the Westbury Formation). The section was further described by Simms and Jeram (2007), who placed the top of the Cotham Member at the change from silt-dominated to darkergrey, mud-dominated sediments and at the top of a series of silty limestones (top of Bed 7 of Simms and Jeram, 2007), $1.47 \mathrm{~m}$ above the mudcracked surface seen on the Waterloo Bay foreshore.

The Cotham Member in Northern Ireland comprises greenish grey and red-brown claystones and silty claystones, with variable amounts of coarse siltstone to fine sandstone, lenticularbedded heterolith. The siltstone and sandstone beds comprise $\mathrm{mm}$ - to $\mathrm{cm}$-scale wave reworked current ripples. Some beds of sandstone display mud drapes and flaser bedding. Beds of hummocky cross-stratified sandstone are noted at outcrop. In many sections and cores beds display a variety of soft sediment deformation features. These sedimentary features are widespread and enable the Cotham Member to be correlated between sections and across into Great Britain (Simms, 2003, 2007).

Fossils are noticeably less common compared to the underlying or overlying units but the Cotham Member locally contains bivalves, many of which are similar to those in the Westbury Formation. The upper parts are increasingly devoid of fossil remains, save for isolated Euestheria sp. and local plant fragments of Naiadites sp. (366.5 m in Carnduff No. 2), but trace fossils on the underside of beds are indicative of interface trails and bivalve resting traces. Additionally, at one outcrop a thin stromatolite bed is seen toward the top of the member. 
The Cotham Member is $6.20 \mathrm{~m}$ thick at Waterloo Bay and elsewhere in the Larne Basin the thickness varies from $9.51 \mathrm{~m}$ in the NIRE 03/08-0001 Borehole, $7.18 \mathrm{~m}$ in the Carnduff No. 2 Borehole, approximately $7.80 \mathrm{~m}$ at Cloghan Point, about $7.62 \mathrm{~m}$ in Colin Glen (Tate, 1864) and perhaps $5.11 \mathrm{~m}$ in Larne No. 1 Borehole. The Cotham Member has not yet been identified in the Lough Neagh Basin while in the Rathlin Basin it is cut out by dolerite sills in the Port More Borehole and not differentiated in the Ballinlea-1 well. It is better known in the Lough Foyle Basin where it is 8.28 m thick in the Magilligan Borehole (Bazley et al. 1997), 9.14 $\mathrm{m}$ in the NIRE 05/08-0003 Borehole (Raine et al., 202X) and 6.28 m at The Lynn (Bazley et al., 1997).

The most interesting features of the Cotham Member are a number of beds or structures that have either value in regional correlation or preserve important events in the geological history of the Late Triassic of the region. They include intervals of soft sediment deformation, a distinctive red-brown mudstone interval, a mud-cracked horizon and the presence of a microbialite.

Deformation has been recorded from sections of the Cotham Member across Northern Ireland (Tate, 1867; Ivimey-Cook, 1975; Bazley et al., 1997; Simms, 2003, 2007). In the Larne Basin deformation is seen in distinct horizons and, although not recorded in the Larne No. 1 Borehole by Ivimey-Cook (1975), it is clearly seen at the Waterloo Bay foreshore and in other nearby boreholes (Carnduff No. 1, Carnduff No. 2, NIRE 03/08-0001), so it presumably was missed in the description of the core. In the Rathlin Basin the same interval is deformed although the intervals appear to be less well defined, perhaps reflecting reduced contrast in the claystones, which lack silt laminae and ripples. Simms (2003) provided a comprehensive list of localities where the deformation was present.

The red-brown coloured interval in the middle of the Cotham Member was first noted by Tate (1864), at Colin Glen, and subsequently in the Larne No. 1 Borehole (Manning and Wilson 1975) and in the Lough Foyle Basin (Bazley et al., 1997). The latter authors 
commented on its superficial resemblance to the red mudstones of the Mercia Mudstone Group and also parts of the Cotham Member in Lincolnshire, eastern England. The unit is therefore widespread and can be recognised in all cores and at most outcrops, except in the Waterloo Bay foreshore section where thermal metamorphism has altered the colour making it difficult to identify.

A hiatus can be recognised in the upper part of the Cotham Member, with cracks extending down as much as $15 \mathrm{~cm}$ and filled with sand, capped by a $2 \mathrm{~cm}$ thick fine-grained wave rippled sandstone. Other sandstones below this level are swaley cross-stratified. It may correlate with other similar surfaces in South Wales and St Audrie's Bay, Somerset, England (Simms, 2003, 2007; Simms and Jeram, 2007).

The recorded presence of $R$. contorta within the red-brown mudstones from the Larne No. 1 Borehole by Manning and Wilson (1975) led to them placing a large part of the Cotham Member in the Westbury Formation. Although Ivimey-Cook (1975) also examined the Larne No.1 Borehole and although he expressed doubts as to whether the borehole samples were in correct order, he did not change the placement of the boundary. This was corrected by Warrington (1997) who revised the base of the Cotham Member downward. Comparison of previous descriptions of the Waterloo Bay foreshore (Tate, 1867; Ivimey-Cook, 1975; Simms and Jeram, 2007) and Larne No. 1 Borehole (Manning and Wilson, 1975) with the boreholes at Carnduff (Boomer et al., 202Xb) confirms the suggestion by Warrington (1997). With a reassignment of these brown beds to the Cotham Member it means that the Westbury is therefore $8.59 \mathrm{~m}$ thick (rather than $13.69 \mathrm{~m}$ ), a similar thickness to Carnduff-2 (7.20 m), NIRE 03/08-0001 (7.19 m) and on the nearby Waterloo Bay foreshore (7.29 m).

\subsubsection{Langport Member}

The lower boundary of the Langport Member is taken at the transition from ripplelaminated and banded siltstones and calcareous siltstones to darker claystones with more porcellanous and structureless limestone. The top of the member, and the top of the 
Lilstock Formation, is marked by a change to dominantly claystone lithologies with increasing faunal diversity and is taken at a marked darkening of mudrocks and reduction in silt and mica. Simms and Jeram (2007) noted that the top of the Langport Member at Waterloo Bay was characterised by a distinctive series of thin micritic limestone beds and laminae, containing rounded and angular clasts of mudstone and abundant compacted bivalves, above which a one metre thick dark grey shaly mudstone was considered to mark the base of the Waterloo Mudstone Formation. This was revised down to below the limestones by Simms et al. 202X.

The Langport Member is up to $6.92 \mathrm{~m}$ at its thickest development, in the Larne Basin in the Carnduff No.2 Borehole and is 7.49 m thick at Waterloo Bay, Larne. In the Lough Foyle Basin it is $4.92 \mathrm{~m}$ thick, with the upper part possibly condensed, in the NIRE 08/05-0003 Borehole and just $2.7 \mathrm{~km}$ to the northwest of it in the Magilligan Borehole $5.44 \mathrm{~m}$ were recorded (Bazley, 1997).

Typical Langport Member lithologies in Northern Ireland include siltstone and claystone heterolith, porcellanous limestone, with common shell beds containing bivalves, largely dominated by Protocardia rhaetica. In the Lough Foyle Basin there is less silt and increased numbers of limestone beds throughout the member in the NIRE 05/08-0003 Borehole and were more abundant in the Magilligan Borehole core (Bazley et al. 1997). In NIRE 05/080003 these limestones are micritic in the lower part, but the top few beds $(55 \mathrm{~cm})$ are composed of grainstones, consisting of ooids and shell debris, with large-scale cross stratification and claystone clasts. A grainstone bed recorded from The Lynn by Bazley et al. (1997) when observed in thin section is a carbonate grainstone to wackestone, comprising ooids and peloids with recrystallised shell fragments. This bed may correlate with the grainstone beds in NIRE 05/08-0003 some $5.5 \mathrm{~km}$ to the north-northwest. In the Larne Basin however, other than the basal limestone and claystone beds, the member is siltier, comprising siltstones and silty claystones. The limestones at the base are present in the less silty part of the member and reflect a short-lived switching to facies that persisted until the base of the Waterloo Formation in the Lough Foyle Basin. 
Some of the thickness variation in the Langport Member across Northern Ireland may be due either to difficulties in identifying the top of the member, erosion of its upper part, or varying accommodation space/sedimentation rates. Furthermore, since the base and top are locally gradational there may well be a degree of boundary diachroneity. Limestones that span the lower boundary complicate matters if used for correlation, as they are independent of silt content. Simms and Jeram (2007) included a series of five limestones immediately above the mud-cracked layer on the Waterloo Bay foreshore section in the upper part of the Cotham Member. In the Lough Foyle Basin, the Langport Member is carbonate-rich and the Cotham Member is carbonate-poor, but in the Larne Basin, carbonate beds straddle the boundary. There is a bed in the Waterloo Bay section at which there is a sharp change to darker grey mudrocks and structureless limestones. Ripple crosslaminated siltstone beds are absent above the boundary and only appear again higher up the section. This change can also be seen in the Carnduff No. 1 and No. 2 cores, but it is more subtle at Cloghan Point.

\section{Lithostratigraphy of the Lias Group}

The Lias Group in Northern Ireland is represented by a clay-dominated succession assigned to a single lithostratigraphic unit, the Waterloo Mudstone Formation. It ranges from the Hettangian to Early Pliensbachian in age and, wherever present, it conformably overlies the Penarth Group. Offshore the Lias Group is widespread around the island of Ireland. Variations in lithofacies, both laterally and vertically, through the Hettangian to Aalenian allow subdivision into a number of formations and members, several of which have been informally defined (e.g. Millson (1987) in the Celtic Sea area and Murphy and Ainsworth (1991) in the Fastnet Basin). Comparisons have been drawn between the Slyne Basin, offshore western Ireland, and the Hebrides Basin (e.g. Trueblood, 1992) with lithostratigraphic terms from the latter being applied to the former basin pending a new lithostratigraphic scheme for offshore Ireland (Copestake et al., 2017; Merlin, in prep). Hebridean terms that have in the past been used in the Slyne Basin include the Broadford Beds (Hettangian-Sinemurian), Pabay Shale, Scalpay Sandstone (Pliensbachian) and 
Portree Shale (Toarcian) formations, as illustrated by the 27/13-1A well (Trueblood, 1992; Trueblood and Morton, 1991).

In addition, an Upper Sinemurian sandstone unit, which was penetrated in the 27/4-1 well has been termed the 'Suisnish Sandstone' (Pritchard, 2016), after a sandstone of equivalent age on the Isle of Skye. However, it is unlikely that the two sandstone units are actually contiguous and a new name will soon be published for the Slyne Basin sandstone member (Merlin, in prep) as well as for some of these other formations that probably are not true correlatives of the Hebrides Basin units. The 'Suisnish Sandstone' in the Slyne Basin correlates approximately with the 'Upper Sinemurian Sandstone' of the North Celtic Sea Basin (Kessler and Sachs, 1995).

Strata assigned to the 'Broadford Beds' by some authors in the Slyne Basin (see above) were deposited in non-marine to marginal marine environments, as indicated in particular by the development of anhydrites. This is quite different from the fully marine 'Broadford Beds' of the Hebrides Basin (see Hesselbo et al., 1998; later renamed as the Breakish and Ardnish formations, see Morton, 2004). For this reason, this unit, as developed in the Slyne Basin, will be given a new name in the Merlin (in prep.) scheme.

The Lower Jurassic succession in two wells from the Slyne Basin, 27/4-1 and 18/20-1, was illustrated by Copestake et al. (2017), together with seismic lines through these wells. The latter well will become a type well in the new lithostratigraphic scheme to be published for offshore Ireland (Merlin, in prep.). This scheme will fully discuss the comparisons between the Hebridean Basin Jurassic stratigraphy and that of offshore Ireland, as well as with other areas of Jurassic development in the UK region, such as the western UK offshore areas (as described by Tappin et al., 1994) and UK onshore basins. In the new scheme, some established UK terms will be utilised where appropriate, whereas in some cases new nomenclature will be introduced. 


\subsection{Waterloo Mudstone Formation}

The Waterloo Mudstone Formation ranges in age from Early Hettangian to Early Pliensbachian. The stratigraphic top of the Waterloo Mudstone Formation (Mitchell, 2004) in Northern Ireland has not yet been encountered, probably removed by erosion across the island. Only Pliensbachian or older strata are preserved (Figure 5) here, whereas younger strata are preserved in basins across the Hebrides (Fyfe et al., 1993). At some localities the Lias Group is entirely absent where Cretaceous rocks rest unconformably on Triassic or older strata.

With the exception of the limestones occurring in the lower part of the formation in the Larne Basin, the base of the Waterloo Mudstone Formation represents a change to a more clay-dominated, more bioturbated and generally darker grey facies than the underlying Lilstock Formation. The formation is also marked by a more diverse fauna than that of the underlying Penarth Group, reflecting more open marine deposition. At the Waterloo Bay foreshore section a one metre thick shaly mudstone may correlate with the 'paper shale' at the base of the Lias Group (Blue Lias Formation) in the Bristol Channel Basin (Simms and Jeram, 2007). The boundary with the underlying Penarth Group in the Rathlin and Lough Foyle basins is taken at the base of claystones that are less micaceous than those of the upper Penarth Group with an increasing abundance of marine indicators, including crinoids, bivalves and Thalassinoides and Teichichnus burrows.

What remains of the Waterloo Mudstone Formation is up to $605 \mathrm{~m}$ thick (seen at Ballinlea1, Boomer et al., 202X), although most boreholes and outcrops record much less. In the Lough Foyle Basin Bazley et al. (1997) estimated a maximum thickness of $180 \mathrm{~m}$, deduced from thicknesses in the Magilligan Borehole (74 m) and Tircreven Burn (52 m). Additional borehole data, that includes the whole Tircreven Sandstone Member as a reference point, confirms this estimate, with 167.2 m of Lias Group strata recorded from the NIRE 0508/0003 Borehole and Tircreven Burn. 
In the north of the Lough Neagh Basin, the Ballymacilroy Borehole penetrated $151 \mathrm{~m}$ of Waterloo Mudstone Formation above a Paleogene sill (Thompson, 1979). No ammonites were recovered but bivalves, crinoids and echinoid spines suggest a Hettangian age while foraminifera and ostracods indicate that the succession is Hettangian to Early Sinemurian in age, and most typical of the Bucklandi Zone (Thompson, 1979). To the southwest of this borehole, at the SW margins of the Lough Neagh Basin, the Mire House Borehole penetrated $124.97 \mathrm{~m}$ of Waterloo Mudstone Formation. Records from elsewhere in the basin are sparse and in the east of the Lough Neagh Basin only the Langford Lodge Borehole encountered Waterloo Mudstone Formation, with around $9 \mathrm{~m}$ estimated from wireline logs and cuttings). The formation is absent through much of the Lagan Valley but, where present such as in Colin Glen and Carr's Glen, does not exceed a few tens of metres. It is only in the Larne Basin, at the Waterloo Bay foreshore section and in the nearby Larne No. 1 and Carnduff boreholes is there any appreciable thickness of Waterloo Mudstone Formation preserved (170.78 $\mathrm{m}$ in the Carnduff No. 2 Borehole).

The formation is dominated by claystones and silty claystones with minor intervals of siltstone, sandstone and limestone, particularly in the lower parts. Limestones are not abundant, a feature that distinguishes the Waterloo Mudstone Formation from the Blue Lias Formation in Britain. Siderite cemented limestones and siltstones are present at White Park Bay.

In Northern Ireland prior to drilling the Ballinlea-1 well (605 m Waterloo Mudstone Formation) its maximum-recorded thickness of $492 \mathrm{~m}$ was in the Port More Borehole, however, dolerite sills accounted for a significant proportion of this total. Dolerite intrusions were also encountered in the Ballinlea-1 well, reducing the net thickness of Waterloo Mudstone to $561 \mathrm{~m}$, but other factors also complicated attempts to estimate the total thickness of the formation here. A shallower interval of Waterloo Mudstone Formation (45 $\mathrm{m}$ thick) lay above an $11 \mathrm{~m}$-thick hard cryptocrystalline limestone and beneath a $95 \mathrm{~m}$ thick dolerite intrusion and overlying Ulster White Limestone Formation. The drillers interpreted 
this as a reverse fault repetition based on the presence of glauconite at the base of the limestone.

Currently the Waterloo Mudstone Formation is not sufficiently well known to warrant further subdivision other than the Tircreven Sandstone Member (Bazley et al. 1997), is recognised south of the Magilligan peninsula. The Tircreven Sandstone Member is best exposed in Tircreven Burn, this unit is approximately $14 \mathrm{~m}$ thick at outcrop but is partly obscured by faults and superficial deposits and it was not until drilling of the NIRE 05/080003 borehole that the full thickness (21.64 m) was cored (Raine et al., 202X).

In general, the Tircreven Sandstone Member comprises a succession of siltstone/sandstone heteroliths and fine sandstones that become more coarse-grained, cleaner and thicker bedded, with cross stratification and bioturbation by Diplocraterion, towards the top. Black carbonaceous claystones in the upper part contain abundant woody material at Tircreven Burn above which are calcareous sandstones with Gryphaea arcuata Lamarck and rare ammonites. In the NIRE 05/08-0003 Borehole the Tircreven Sandstone Member lacks the abundant carbonaceous material and there is an upwards gradational change from an upper, 4 m-thick, fossiliferous sandy limestone to dark grey calcareous mudstone.

The youngest parts of the Waterloo Mudstone Formation, of Early Pliensbachian age, were encountered in the Port More Borehole and Ballinlea-1 well. At outcrop the Waterloo Mudstone Formation of Early Pliensbachian age (Ibex zone) is exposed at Portnakillew near Kinbane Head (Wilson and Robbie, 1966) and also at Oweynamuck at the east end of White Park Bay (Wilson and Manning, 1978; Simms and Edmunds, 202X).

\section{Summary}

Relatively thin exposures of the uppermost Triassic to Lower Jurassic interval are recognised onshore in Northern Ireland, while much thicker sequences are now known from both 
onshore and offshore basins on the island of Ireland. Only the uppermost Triassic Penarth Group and lowermost parts of the Lower Jurassic sequence have been studied in detail and, where present, they often provide largely continuous records through this important period in earth history. However, minor differences in the completeness of the records between basins reflect the unique structural setting and independent syn-sedimentary processes that are unique to each basin. Facies variability and the succession of individual units shows strong similarities with contemporaneous units in southern Britain suggesting widespread development of the distinct facies in the Penarth Group in particular, though there remains the possibility that some of the more marginal marine units may be diachronous.

The youngest sediments encountered onshore are of Early Pliensbachian age, while some of the offshore basins may well demonstrate continuing sedimentation through into the Middle and Late Jurassic.

\section{Acknowledgements}

The authors wish to greatly acknowledge the external reviewers Prof John C.W. Cope and Prof Stephen Hesselbo. This work was supported through Department for the Economy and British Geological Survey funding. R. Raine publishes with the permission of the Executive Director of the British Geological Survey (UKRI). This paper was carried out under the SLA with the Department and is published with the Department's agreement. 


\section{References}

911

Ainsworth N.R., O'Neill M., Rutherford M.M., Clayton G., Horton N.F., Penney R.A., 1987. Biostratigraphy of the Lower Cretaceous, Jurassic and uppermost Triassic of the North Celtic Sea and Fastnet Basins. In: Brooks J., Glennie K.W. (Eds.) Petroleum Geology of North West Europe. Graham and Trotman, London, pp. 611-622.

Ainsworth N.R., O'Neill M., Rutherford M.M., 1989. Jurassic and Upper Triassic biostratigraphy of the North Celtic Sea and Fastnet Basins. In: Batten D.J., Keen M.C. (Eds.) in Northwest European Micropalaeontology and Palynology. British Micropalaeontological Society Series, Ellis Horwood, Chichester, pp. 1-43.

Bazley, R.A.B., Brandon, A., Arthurs, J.W., 1997. Geology of the Country around Limavady and Londonderry. Geological Survey of Northern Ireland, Technical Report GSNI/97/1. 96 pp.

Boomer, I., Azmi, A., Copestake, P., Raine, R., 202Xa. Lower Jurassic (Hettangian-Pliensbachian) microfossil biostratigraphy of the Ballinlea-1 well, Rathlin Basin, Northern Ireland, United Kingdom. This issue.

Boomer, I., Copestake, P., Raine, R., Azmi, A., Fenton, J., Page, K., O'Callaghan, M., 202Xb. Palaeoenvironments and geochemistry of the Late Triassic to Early Jurassic interval of County Antrim, Northern Ireland. This issue.

Bridge. D.McC., Carney. J.N., Lawley. R.S., Rushton. A.W.A., 1998. Geology of the country around Coventry and Nuneaton: memoir for 1:50 000 geological sheet 169 (England and Wales). Stationary Office, London, $85 \mathrm{pp}$.

Byrne, K., 2015. Revised Structural Evolution of the North Celtic Sea Basin Based on Modern 2D and 3D Seismic Data. AAPG Datapages/Search and Discovery Article \#90226. 2015 European Regional Conference and Exhibition, Lisbon, Portugal, May 18-19, 2015.

Carruthers, R.M., Beamish, D., Heaven, R.E., Legg, I.C., Mitchell, W.I., Reay, D.M., Walker, A.S.D., 1997. Regional interpretation of gravity and aeromagnetic data from Northern Ireland. British Geological Survey Technical Report WK/96/05/C.

Chapman, T.J., Broks, T.M., Corcoran, D.V., Duncan, L.A., Dancer, P.N., 1999. The structural evolution of the Erris Trough, offshore northwest Ireland, and implications for hydrocarbon generation. In: Fleet A.J., Boldy, S.A.R. (Eds.), Petroleum Geology of Northwest Europe: proceedings of the 5th Conference, pp. 455-469. Published by the Geological Society, London.

Colin, J.P., loannides, N.S., Vining, B., 1992. Mesozoic stratigraphy of the Goban Spur, offshore southwest Ireland. Marine and Petroleum Geology 9, 527-541.

Copestake, P., Ainsworth, N.R., Bailey, H.W., Dominey, S.J., Donato, J.A., Farrimond, P.R., Gallagher, L.T., Gehlen, M., Gueinn, K., Hampton, M., Lavis, O.M., Loy, T., Riley, L.A., Wright, T.D., Stevenson, C., 2017. A biostratigraphic, lithostratigraphic and sequence stratigraphic framework of offshore Ireland. Presentation, Atlantic Ireland 2017 Conference, Dublin. https://www.pip.ie/page/402

Croker, P.F., Klemperer, S.L., 1989. Structure and stratigraphy of the Porcupine Basin: relationships to deep crustal structure and the opening of the North Atlantic: Chapter 29: European-African 
Margins. In: Tankard, A.J., Balkwill, H.R. (Eds.), Extensional Tectonics and Stratigraphy of the North Atlantic Margins. AAPG Memoir 46, 445-459.

Dancer, P.N., Algar, S.T., Wilson, I.R., 1999. Structural evolution of the Slyne Trough. In: Fleet A.J., Boldy, S.A.R. (Eds.), Petroleum Geology of Northwest Europe: proceedings of the 5th Conference, pp. 445-453. Published by the Geological Society, London.

Dancer, P.N., Kenyon-Roberts, S.M., Downey, J.W., Baillie, J.M., Meadows, N.S., Maguire, K., 2005. The Corrib Gas Field, offshore west of Ireland. In: Dore, A.G., Vining, B.A. (Eds.), Petroleum Geology: North-West Europe Global Perspectives, Proceedings of the 6th Petroleum Geology Conference. London: The Geological Society, 1035-1046.

Dobson, M.R., Evans, D., 1974. Geological structure of the Malin Sea. Journal of the Geological Society, London 130, 475-478.

Dobson, M.R., Whittington, R.J., 1979. The geology of the Kish Bank Basin. Journal of the Geological Society of London 136, 243-249.

Dunford, G.M., Dancer, P.N., Long, K.D., 2001. Hydrocarbon potential of the Kish Bank Basin: integration within a regional model for the Greater Irish Sea Basin. In: Shannon, P.M., Haughton, P.D.W., Corcoran, D.V. (Eds.), The Petroleum Exploration of Ireland's Offshore Basins. Geological Society, London, Special Publications 188, 135-154.

Evans, D. Kenolty, N., Dobson, M.R., Whittington, R.J., 1980. The Geology of the Malin Sea. Report of the Institute of Geological Sciences 79/15, 44 pp.

Ewins, N.P., Shannon, P.M., 1995. Sedimentology and diagenesis of the Jurassic and Cretaceous of the North Celtic Sea and Fastnet basins. In: Croker, P.F., Shannon, P.M. (Eds.), The Petroleum Geology of Ireland's Offshore Basins. Geological Society, London, Special Publications 93, 139-169.

Fletcher, T.P., 1977. Lithostratigraphy of the Chalk (Ulster White Limestone Formation) in Northern Ireland. Report of the Institute of Geological Sciences 77/24, pp. 33.

Fowler, A., Robbie, J.A., Bullerwell, W., Stubblefield, C.J., Ramsbottom, W.H.C., 1961. Geology of the country around Dungannon (one-inch geological sheet 35). Memoirs of the Geological Survey of Northern Ireland, HMSO, Belfast, 274 pp.

Fyfe, J.A., Long, D., Evans, D., 1993. United Kingdom offshore regional report: the geology of the Malin-Hebrides sea area. British Geological Survey, HMSO, London, 91 pp.

Gallois, R.W., 2008. The stratigraphy of the Penarth Group (Late Triassic) of the East Devon coast. Geoscience in south-west England 11, 287-297.

Gallois, R.W., 2009. The lithostratigraphy of the Penarth Group (Late Triassic) of the Severn Estuary area. Geoscience in south-west England 12, 71-84.

Geological Survey of Northern Ireland, 1997. Northern Ireland. Solid Geology (Second Edition). 1:250 000. British Geological Survey, Nottingham.

Gray, W., 1870. Seventh Annual Report of the Belfast Naturalists' Field Club, pp. 49-50.

Green, P.F., Duddy, I.R., Hegarty, K.A., Bray, R.J., Sevastopulo, G., Clayton, G., Johnson, D., 2000. The post-Carboniferous evolution of Ireland: evidence from thermal history reconstruction. Proceedings of the Geologists' Association 111, 307-320. 
Green, P.F., Duddy, I.R., Bray, R.J., Duncan, W.I, Corcoran, D.V., 2001. The influence of thermal history on hydrocarbon prospectivity in the Central Irish Sea Basin. In: Shannon, P.M., Haughton, P.W., Corcoran, D.V. (Eds.), The Petroleum Exploration of Ireland's Offshore Basins. Geological Society, London, Special Publications 188, 171-188.

Hartley, J.J., 1933. Notes on fossils recently obtained from the 'Chloritic' Conglomerate of Murlough Bay, Co. Antrim. Irish Naturalist Journal 4, 238-239.

Hernon, K., English, K.L., Hanrahan, M., Morgan, C., 2017. North Celtic Sea Basin, Offshore Ireland; New Opportunities in a Mature Basin. American Association of Petroleum Geologists Datapages/Search and Discovery Article No. 90310, 2017 AAPG/SEG International Conference and Exhibition, London, England, October 15-18, 2017.

Hesselbo, S.P., Oates, M.J., Jenkyns, H.C., 1998. The lower Lias Group of the Hebrides Basin. Scottish Journal of Geology 34, 23-60.

Higgs, K.T., and Beese, A.P., 1986. A Jurassic microflora from the Colbond Clay of Cloyne, County Cork. Irish Journal of Earth Sciences 7, 99-109.

Higgs, K.T., and Jones, G.LI. 2000. Palynological evidence for Mesozoic karst at Piltown, Co. Kilkenny. Proceedings of the Geologists' Association 111, 355-362.

Howard, A.S., Warrington, G., Ambrose, K., Rees, J.G., 2008. A formational framework for the Mercia Mudstone Group (Triassic) of England and Wales. British Geological Survey, Research Report RR/08/04. 33 pp.

Ivimey-Cook, H.C., 1975. The stratigraphy of the Rhaetic and Lower Jurassic in East Antrim. Bulletin of the Geological Survey of Great Britain 50, 51-69.

Johnston, S., Dore, A.G., Spencer, A.M., 2001. The Mesozoic evolution of the southern North Atlantic region and its relationship to basin development in the south Porcupine Basin, offshore Ireland. In: Shannon, P.M., Haughton, P.W., Corcoran, D.V. (Eds.), The Petroleum Exploration of Ireland's Offshore Basins. Geological Society, London, Special Publications 188, 237-263.

Kessler, L.G., Sachs, S.D., 1995. Depositional setting and sequence stratigraphic implications of the Upper Sinemurian (Lower Jurassic) sandstone interval, North Celtic Sea/St George's Channel Basins, offshore Ireland. In: Croker, P.F., Shannon, P.M. (Eds.) The Petroleum Geology of Ireland's Offshore Basins. Geological Society, London, Special Publications 93, 171-192.

Lamplugh, G.W., Kilroe, J.R., M'Henry, A., Seymour, H.J., Muff, H.B., Wright, W.B., 1904. The geology of the country around Belfast: explanation of the Belfast colour-printed drift map, Memoirs of the Geological Survey of Ireland, HMSO, Dublin. $166 \mathrm{pp}$.

Langtry, G., 1875. On the occurrence of the Middle Lias at Ballycastle. Report of the forty-fourth meeting of the British Association for the Advancement of Science, Belfast for 1874. Transactions of the Sections, p. 88.

Maddox, S. J., Blow, R., Hardman, M., 1995. Hydrocarbon prospectivity of the Central Irish Sea Basin with reference to Block 42/12, offshore Ireland. In: Croker, P.F., Shannon, P.M. (Eds.), The Petroleum Geology of Ireland's Offshore Basins. Geological Society, London, Special Publications 93, pp. 59-77.

Maingarm, S., Izatt, C., Whittington, R.J., Fitches, W.R., 1999. Tectonic evolution of the southern Central Irish Sea Basin. Journal of Petroleum Geology 22, 287-304. 
Manning P.I., Robbie J.A., Wilson H.E., 1970. Geology of Belfast and the Lagan Valley, Memoir of the Geological Survey of Northern Ireland, 242 pp.

Manning, P.I., Wilson, H.E., 1975. I. The stratigraphy of the Larne Borehole, County Antrim. Bulletin of the Geological Survey of Great Britain 50, pp. 1-50.

McLean, A.C., 1978. Evolution of fault controlled ensialic basins in northwestern Britain. In: Bowes, D.R., Leake, B.E., (Eds.) crustal evolution in northwestern Britain and adjacent regions. Geological Journal Special Issue 10, 325-346.

Merlin Energy Resources Consortium, in prep. The Standard Stratigraphic Nomenclature of Offshore Ireland: An Integrated Lithostratigraphic, Biostratigraphic and Sequence Stratigraphic Framework. Project IS16/04 Atlas, for Petroleum Infrastructure Programme (PIP).

Millson, J.A., 1987. The Jurassic evolution of the Celtic Sea basins. In: Brooks J., Glennie K. W. (Eds.), Petroleum Geology of North West Europe. Graham and Trotman, London, pp. 599-610.

Mitchell, W.I., 2004. Chapter 10 Triassic. In: Mitchell, W.I. (Ed.), The Geology of Northern Ireland Our natural Foundation (Second Edition). Geological Survey of Northern Ireland Belfast, pp. 133144.

Morton, N., 2004. 8 The Hebrides Basin. In: Simms, M.J., Chidlaw, N., Morton, N., Page, K.N. (Eds.). British Lower Jurassic Stratigraphy. Geological Conservation Review Series, No. 30, Joint Nature Conservation Committee, Peterborough, pp. 315-374.

Murphy, N.J., Ainsworth, N.R., 1991. Stratigraphy of the Triassic, Lower Jurassic and Middle Jurassic (Aalenian) from the Fastnet Basin, Offshore South-west Ireland. Marine and Petroleum Geology 8, 417-424.

Naylor, D., 1992. The post-Variscan history of Ireland. In: Parnell, J. (Ed.), Basins on the Atlantic Seaboard: Petroleum Geology, Sedimentology and Basin Evolution. Geological Society, London, Special Publications 62, pp. 255-275.

Naylor, D., Shannon, P.M. 1982 The Geology of Offshore Ireland and West Britain, Graham and Trotman, London, pp. 161.

Naylor, D., Haughey, N., Clayton, G., Graham, J.R., 1993. The Kish Bank Basin, offshore Ireland. In: Parker, J.R. (Ed.), Petroleum Geology of Northwest Europe: Proceedings of the 4th Conference. Geological Society, London, pp. 845-855.

Naylor, D., Philcox, M.E. Clayton, G., 2003. Annaghmore-1 and Ballynamullan-1 Wells, Larne-Lough Neagh Basin, Northern Ireland. Irish Journal of Earth Sciences 21, 47-69.

Old, R.A., Sumbler, M.G., Ambrose, K. 1987. Geology of the country around Warwick : memoir for 1:50,000 geological sheet 184 (England \& Wales). HMSO, London, 93 pp.Partington, M.A., Copestake, P., Mitchener, B., Underhill, J.A., 1993. Biostratigraphic calibration of genetic stratigraphic sequences in the Jurassic - lowermost Cretaceous (Hettangian to Ryazanian) of the North Sea and adjacent areas. In: Parker, J.R. (Ed.), Petroleum Geology of Northwest Europe; Proceedings of the 4th Conference. Geological Society, London, 371-386.

Portlock, J.E., 1843. Report on the Geology of the County of Londonderry, and of Parts of Tyrone and Fermanagh. HMSO, Dublin, 784 pp. 
Pritchard, G., 2016. Key elements of the petroleum systems of the Rockall and Slyne-Erris basins. Atlantic Ireland Conference, Dublin, $1^{\text {st }}-2^{\text {nd }}$ November, 2016. https://www.pip.ie

Raine, R.J., Azmi, A., Copestake, P., Fenton, J., Boomer, I. 202X. Late Triassic to Early Jurassic sedimentation in the Lough Foyle Basin of Co. Londonderry, Northern Ireland. This issue.

Robinson, K.W., Shannon, P.M., Young, D.G.G., 1981. The Fastnet Basin; an integrated analysis. In: Illing, L.V., Hobson, G.D. (Eds.), Petroleum Geology of the Continental Shelf of North-West Europe. Heyden, London. pp. 444-454.

Rowell, P. 1995. Tectono-stratigraphy of the North Celtic Sea Basin. In: Croker, P.F., Shanno, P.M. (Eds.), The Petroleum Geology of Ireland's Offshore Basins. Geological Society, London, Special Publications 93, 101-137.

Savage, R.J.G., 1963. Upper Lias ammonite from Cretaceous conglomerate of Murlough Bay. Irish Naturalists' Journal 14, 179-180.

Schmidt, S., Worden, R.H., Fisher, Q.J., 2006. Sedimentary facies and the context of dolocrete in the Lower Triassic Sherwood Sandstone Group: Corrib Field, west of Ireland. Sedimentary Geology 187, 205-227.

Shannon, P.M., 1995. Permo-Triassic development of the Celtic Sea region, offshore Ireland. In; Boldy, S.A.R. (Ed.), Permian and Triassic Rifting in Northwest Europe. Geological Society, London, Special Publications 91, 215-237.

Shelton, R., 1997. Tectonic evolution of the Larne Basin. In: Meadows, N.S., Trueblood, S.P., Hardman, M. \& Cowan, G. (Eds.), Geological Society, London, Special Publications 124, pp. 113-133.

Simms, M.J., 2003. Uniquely extensive seismite from the latest Triassic of the United Kingdom: evidence for bolide impact? Geology 31, 557-560.

Simms, M.J., 2007. Uniquely extensive soft-sediment deformation in the Rhaetian of the UK: evidence for earthquake or impact? Palaeogeography, Palaeoclimatology, Palaeoecology 244, 407423.

Simms, M.J., Edmunds, M., 202X. Sinemurian and Pliensbachian ammonites of north Antrim. This volume.

Simms, M.J., Jeram, A.J., 2007. Waterloo Bay, Larne, Northern Ireland: a candidate Global Stratotype Section and Point for the base of the Hettangian Stage and Jurassic System. ISJS Newsletter 34, 5068.

Smith, C., 1995. Evolution of the Cockburn Basin: implications for the structural development of the Celtic Sea basins. In: Croker, P.F., Shannon, P.M. (Eds.) The Petroleum Geology of Ireland's Offshore Basins. Geological Society, London, Special Publications 93, 279-295.

Stoker, M.S., Stewart, M.A., Shannon, P.M., Bjerager, M., Nielsen, T., Blischke, A., Hjelstuen, B.O., Gaina, C., McDermott, K., Ólavsdóttir, J., 2017. An overview of the Upper Palaeozoic - Mesozoic stratigraphy of the NE Atlantic region. In: Péron-Pinvidic, G., Hopper, J.R., Stoker, M.S., Gaina, C., Doornenbal, J.C., Funck, T., Árting, U.E. (Eds.), The NE Atlantic region: a reappraisal of Crustal Structure, Tectono Stratigraphy and Magmatic Evolution. Geological Society, London, Special Publications 447, 11-68. 
Tappin, D.R., Chadwick, R.A., Jackson, A.A., Wingfield, R.T.R., Smith, N.J.P., 1994. United Kingdom offshore regional report: the geology of Cardigan Bay and the Bristol Channel. HMSO for the British Geological Survey, London, 1-107.

Tate, M.P., Dobson, M.R., 1989. Late Permian and early Mesozoic rifting and sedimentation offshore NW Ireland. Marine and Petroleum Geology 6, 49-59.

Tate, R., 1864. On the Liassic strata of the neighbourhood of Belfast. Quarterly Journal of the Geological Society of London 20, 103-114.

Tate, R., 1867. On the Lower Lias of the north-east of Ireland. Quarterly Journal of the Geological Society of London 23, 291-305.

Tate, R., 1870. Middle Lias in North East Ireland. Quarterly Journal of the Geological Society 26, 324325.

Thompson, S.J., 1979. Preliminary Report on the Ballymacilroy No.1 Borehole, Ahoghill, Co. Antrim, Geological Survey of Northern Ireland, Open File Report 63, pp. 15.

Thompson, S J., 1997. Geology of the country around Antrim. 1:50 000 Geological Sheet 28 (Antrim). Geological Survey of Northern Ireland, Technical Report GSNI/97/6, pp. 154.

Trueblood, S., 1992. Petroleum geology of the Slyne Trough and adjacent basins. In: Parnell, J. (Ed.), Basins of the Atlantic Seaboard: Petroleum Geology, Sedimentology and Basin Evolution. Geological Society, London, Special Publications 62, pp. 315-326.

Trueblood, S., Morton, N., 1991. Comparative sequence stratigraphy and structural styles of the Slyne Trough and Hebrides Basin. Journal of the Geological Society, London 148, 197-201.

Versey, H.E., 1958. Derived ammonites in the basal Cretaceous conglomerate. Geological Magazine 95, p. 440.

Warrington, G., 1997. The Penarth Group-Lias Group succession (Late Triassic-Early Jurassic) in the East Irish Sea Basin and neighbouring areas: a stratigraphical review. In: Meadows, N.S., Trueblood, S.P., Hardman, M. \& Cowan, G. (Eds.), Petroleum Geology of the Irish Sea and Adjacent Areas, Geological Society, London, Special Publications 124, pp. 33-46.

Warrington, G., Audley-Charles, M.G., Elliott, R.E., Evans, W.B., Ivimey-Cook, H.C., Kent, P.E., Robinson, P.L., Shotton, F.W., Taylor, F.M., 1980. Triassic. Geological Society, Special Report 13.

Wilson, D., Davies, J.R., Fletcher, C.J.N., Smith, M., 1990. Geology of the South Wales Coalfield, Part $\mathrm{VI}$, the country around Bridgend. Memoir of the British Geological Survey, Sheets 261 and 262. (England and Wales).

Wilson, H.E., Manning, P.I., 1978. Geology of the Causeway Coast. Memoir of the Geological Survey of Northern Ireland, Sheet 7. HMSO, Belfast, pp. 172.

Wilson, H.E., Robbie, J.A., 1966. Geology of the Country around Ballycastle (One-inch geological sheet 8), HMSO, Belfast, pp. 370.

Ziegler, P.A., 1990. Geological Atlas of Western and Central Europe. $2^{\text {nd }}$ Edition. Shell Internationale Petroleum Maatschappij B.V. 
